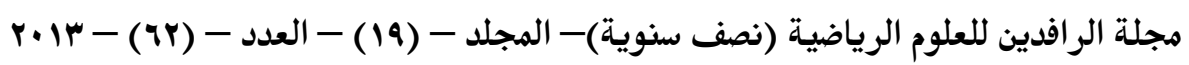

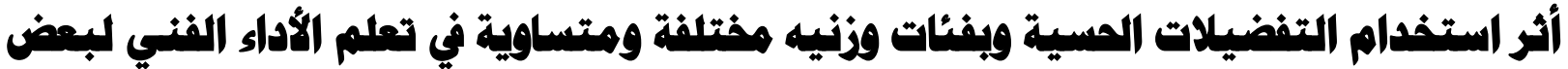 مسكات المصارعة المرة وريكات$$
\text { أ.د. محمد خضر أسمر الحياني" . زياد طارق حامد }
$$

dr.alasmar@yahoo.com فرع الالعاب الفرقية/كلية التربية الرياضية/جامعة الموصل/العراق/"

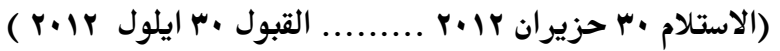

يهرف البحث الى الكثف عن الفروق بين المجاميع التي تستخدم فئات وزنيه مختلفة والمجاميع التي تستخدم فئات وزنيه متساوية بين التفضيلات الحسية الثلاث (البصرية، والسمعية، واللمسية) في تعلم الأداء الفني لبعض مسكات المصارعة الحرة. واستخدم الباحثان المنهج التجريبي، وتكونت عينة البحث من ثلاث شعب من طلاب السنة الاراسية الثالثة في كلية

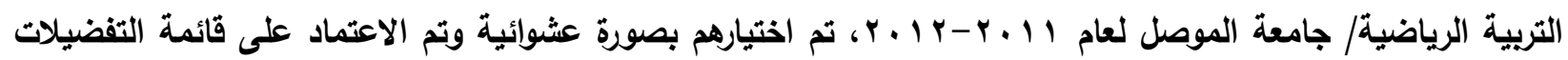
الحسية في اختيار مجموعات البحث الثلاث،والمعدة من قبل الباحثان والبالغ عدد فقراتها (Y) (Y) فقرة وتتمتع القائمة

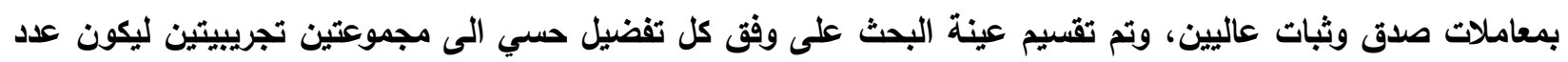
المجاميع التجريبية ست مجاميع ضمن ثلاث برامج تعليمية، ثلاث مجاميع تجريبية تمارس بفئات وزنيه مختلفة وثيلاث

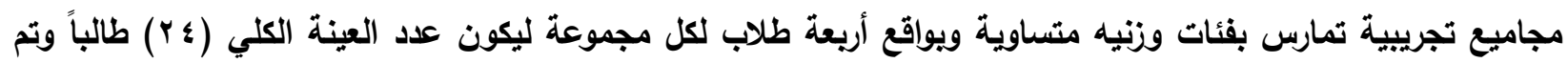
إجراء التكافؤ والتجانس بين المجاميع التجريبية واستخدم الباحثان القياس والإختبار والمقابلة والإستبيان وسائل لجمع ولئ ولئه البيانات واستخدم الباحثان الوسائل الإحصائية الآتية: (الوسط الحسابي، ولانحراف المعياري، ومعامل الارتباط المتعدد، ومعامل الارتباط البسيط، واختبار"ت" لوسطين حسابيين غير مرتبطين متساويين بالعدد ومعادلة كيورد -ريتشاردسون (K-R21)). واستتتج الباحثان أن المجاميع التجريبية (البصرية، والسمعية، واللمسية) ويفئات وزنيه مختلفة حققوا أفضلية التعلم على الى المجاميع التجريبية (البصرية، والسمعية، واللمسية) ويفئات وزنيه متساوية للمسكات الخمسة التي تضمنها البرنامج التعليمي وأوصى الباحثان ضرورة إستخدام التفضيل الحسي المفضل للطلاب ويفئات وزنية مختلفة في إعداد البرامج التعليمية لما له من فوائد في تعلم الأداء الفني لمسكات المصارعة الحرة. الكلمات المفتاحية: التفضيلات الحسبة - نفئات وزنية مختلفة ومتساوية.

\section{The Effect of using Sensory Preferences with Different and Equal Weights categories on Learning Technical Performance in Some Free Wrestling Handles.}

Prof. Dr. Mohammed K. Asmer.

Lecture Ziyad T. Hamed.

\section{$\underline{\text { Abstract }}$}

The aim of the study was to explore the differences between the groups they have used different weights sorts and the groups they have used equal weights sorts between the three sensory preferences (Visual, Auditory, Touchable) on learning performance in some free wrestling handles. Sample of study was consisted from three classes from third stage in the college of sport education, University of Mosul for the year 2011-2012, they were randomly 
choosen. We depended on the sensory preferences inventory to choose the three research groups, the inventory was consisted of (21) item, with high validity and reliability coefficients.

Sample of study was divided according to each sense preference into two experimental groups in order to be six experimental groups, includes three learning programs three experimental groups practices with different weight sorts and three experimental groups practice with equal weights categories, each groups consisted of (4) students, so the total numbers of the sample was (24) students.

Equivalence and homogeneous was done between the six groups, the researchers were used test measurement, interview, and questionnaire as a tools to collect data, also we used the following statistical means such as (Arithmetic mean, standard deviation, simple correlation coefficient, Multiple correlation coefficient, $t$. Test for two uncorrelated means equal group and $\mathrm{K}-\mathrm{R} 21$ coefficient ).

The researchers have attained that the experimental groups (Visual, Auditory, Touchable) practice with different weight categories was obtained better learning than the experimental groups (Visual, Auditory, Touchable) practice with equal weight categories for the five free wrestling handles in the learning program.

Finally the researchers has recommended that its important to use the prefer sensory preference for the students with different weight categories in preparing learning programs in learning technical performance in free wrestling handles.

Keywords: Sensory Preference - Different and Equal Weights Categories

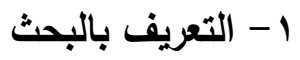

1- 1 - 1 مقدمة البحث وأهميته

يُعـد أسـلوب التعلم على وفق التفضـيلات الحسبية احــ هـذه الأسـاليب التي مـن خلالهـا يفضـل المـتعلم

المعلومات التي تأتي عن طريق الحواس سواء كانت (بصرية، أم سمعية، أو لمسية) لأنها تكون اكثر استيعابا وفهما لكيفية الإدراك والمعالجة والتفاعل مع البيئة التعليمية "عندما يفهم الطلاب حواس التعلم (البصرية، السمعية، اللمسية) فانه يكون لديهم أداة لتكوين المعنى والتعبير عن استيعابهم "(السلطي والريماوي، 9 . . ب، 0 1Y)، ونظراً لما تحتويه لعبة المصسارعة من مهارات حركية متتوعة ولإعداد أساليب فعاله في المجال العملي، ومن أجل الاستفادة من تعدد الفئات الوزنيه للطلاب في أثناء تطبيقهم لمفردات الوحدة التعليمية كأسلوب يمكن من خلاله اعتماد مبدأ التتوع بالأداء الفني في تعلم المسكات سواء من وضـع الوقوف أم الجلوس في لعبـة المصارعة، إذ يذكر (عثمان) "تتطلب عملية التعلم الحركي استخدام أساليب وإجراءات تضمن الوصول الى الهدف من العملية التعليمية، وإتباع الأسلوب العلمي السليم في عملية التعليم والتعلم الخاصـة بتعلم المهارات الحركية المختلفة، فضـلا عن إنباع الخطوات الصحيحة في

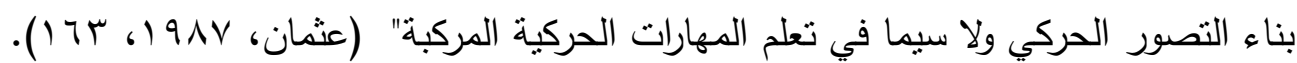
لذا حرص الباحثان على إستثمار هذا التتوع بالفئات الوزنيه على وفق قانون لعبة المصارعة للمتقدمين في تعلم الأداء الفني للمسكات خلال الأداء العملي مع متعلم اقل وزناً وللفئة الوزنية نفسها وأكثر وزنا بعد توزيعهم على وفق تفضيلاتهم الحسية (البصرية،السمعية، اللمية) على اعتبار إننا نستقبل معلومات عبر حواسنا المختلفة، لذا تعد القنوات الحسية قنوات مهمة في عمليـة التعلم "فحواس البصر والسمع واللمس تؤدي دوراً بـارزاً في التعلم الجديد"

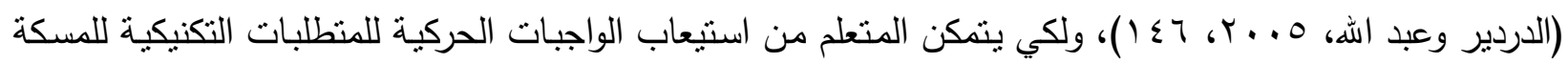
وتكوين فهم عميق للمسار الحركي عند الأداء مع فئات وزنيه مختلفة لتعلم الأداء الفني (للمسكة) بما قد يسهل حل 
الواجب الحركي المراد تعلمه بشكل صحيح، إذ يشير (محجوب)" إذا زادت كمية المتغيرات في أنثكال التمرين أعطت

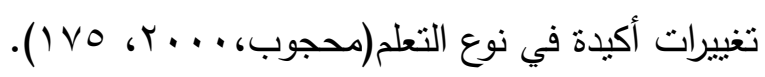
من هنا تكمن أهمية البحث والحاجة اليه كمحاولة علمية لتجريب أثر استخدام التفضيلات الحسية وبفئات وزنيه مختلفة في تعلم الأداء الفني لبعض مسكات المصارعة الحرة. r-1 r r r مشكة البحث

يختلف المتعلمون في أساليب تعلمهم طبقاً للفروق الفردية وكيفية تفضيلاتهم الحسية (البصرية، والسمعية، واللمسية) في فهم ومعالجة المعلومات، فضلاً عن الأداء الفني(للمسكة) في لعبة المصارعة يكون بشكل ثنائي بين الطلاب ضمن فئات وزنية محددة، لذا ظهرت الحاجة الى فهم التفضيلات الحسية للطلاب وكيفية تعلمهر مسكات لعبة المصسارعة داخل الصفوف الدراسية غير المتجانسة نتيجة لعدم الاهتمام بها من قبل المدرسين وتبنيهم أساليب تقليدية خلال تتفيذ الطلاب مفردات الوحدة التعليمية لمادة المصارعة مما حذا بالباحثين للعمل على تفعيلها بوصفها انـه لا يوجد أسلوب تعليمي واحد يحقق أفضل النتائج لجميع الطلاب نتيجة للفروق الفرديـة للتعلم ومن هنا برزت مشكلة البحث الحالي في الإجابة التساؤل الآتي: هل أن استخدام التفضيلات الحسية وبفئات وزنيه مختلفة ومتسـاوية ستسهم في تعلم الأداء الفني لبعض الفض مسكات المصارعة الحرة ؟ r-1 يهدف البحث الى الكثف عن الفروق بين المجاميع التي تستخدم فئات وزنية مختلفة والمجاميع التي تستخدم فئات وزنية منسـاوية بين التفضيلات الحسية التثلاث (البصرية، والسمعية، واللمسية) في تعلم الأداء الفني لبعض مسكات المصارعة الحرة.

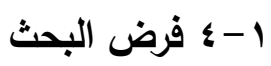
- - لا توجد فروق ذوات دلالة معنوية بين المجاميع التي تستخدم فئات وزنية مختلفة والمجاميع التي تستخدم أوزان متساوية بين التضضيلات الحسية الثناث (البصرية، والسمعية، واللمسية) في تعلم الأداء الفني لبعض مسكات المصارعة الحرة.

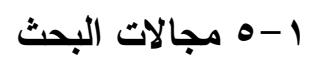

1-0-1 المجال البشري: طلاب السنة الدراسية الثالثة في كلية التربية الرياضية- جامعة الموصل.

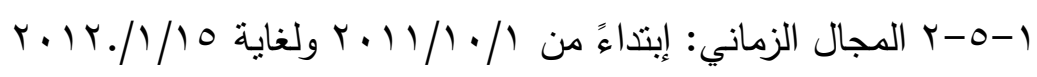
1-0-r المجال المكاني: قاعة المصارعة - كلية التربية الرياضية- جامعة الموصل. 
يشير مصـطلح التفضيلات الحسية الى الحواس المستخدمة في تتظيم المعلومـات والتفاعل مـع البيئة التعليمية، فالحاسة المفضلة لدى الفرد عنصرا مهما في أسلوب تعلمه (الدردير وعبد الله، 0. . ب ، 10 (). ويعرفها الباحثنان بأنها الحاسـة التي يُفضلها ويستخدمها المتعلم عند أول إستجابة يصدرها خلال المواقف التعليمية المختلفة عند تعلم لعبة المصارعة الحرة لكي يقوم الدماغ بتشفير المعلومات ثم تقسيرها ومن ثم فهمها. 1 r- r- r الفئات الوزنية: وهي الأوزان المحددة طبقا للقانون الدولي للعبة المصارعة وفق المادة (؟) (قانون المصـارعة الدولي للهواة، $\cdot(r \cdot .0$ 1 هو نظاما خاصا لحركات تؤدى بان واحد او بالتعاقب مستتدا الى تتظيم مجدي للعلاقة بين القوى الخارجية المؤثرة على الرياضي، إن هذه القوى يجب ان تستتمر بشكل كامل وفعال للوصول الى النتائج الهادفة ( الكبيسي، $\cdot(\wedge \wedge, r \cdot \Lambda$

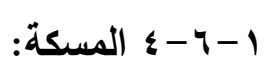
عبارة عن حركات منظمة بشكل مجدي وتتم هذه الحركات أو قسم منها بان واحد او بالتدريج، بحيث يكون تأثثرها موجها على الخصم ومتبادلا بين القوى الخارجية والداخلية (الكبيسي، سمو (1، ـ0). r- الإطار النظري والدراسات السابقة r - r الإطار النظري r - - التفضيلات الحسية وأساليب التعلم الحركي: لقد اهتم العديد من الباحثين بالتقضيلات الحسية وطبيعتها وكيفية حصول المتعلم على المعلومات وكيفية تمثيلها وتحويلها الى معرفة وكيفية تخزينها وطريقة استخدامها في أثناء الأداء التطبيقي، إذ إن استخلاص المعلومات من الخبرات الحسية وترميزهـا وتتظيمها وضمها الى مخزون في الذاكرة يختلف من متعلم الى آخر طبقا للفروق الفردية للمتعلمين من حيث قدراتهم العقلية واستعداداتهم واختلاف استجابة كل منهم للموقف التعليمي. ويذكر (عثمان)" إن الاجراءات والأساليب المتبعة في التعلم الحركي هي: مني ا - أساليب تعتمد على استخدام حاسـة البصر من خلال اعطاء النموذج العملي من المدرس أو من خلال استخدام الوسائل التعليمية والبصرية. r- أساليب تعتمد على الثرح الثفوي والإرشاد والتوجيه والتوضيح.

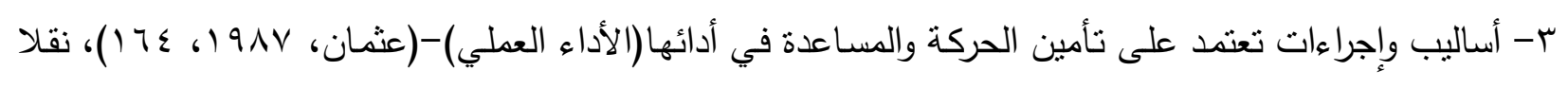
عن ( Grossing,1981) 


\section{r - - - مفهوم الاداء الفتي (المسكات) في المصارعة الحرة}

إن لكل مسكة هدف معين وهو حل واجب حركي نتيجة توفر وحدوث حالات ملائمة تمكن اللاعب المدافع أو المهاجم في اثتاء النزال من الاداء الفني المطلوب لتحقيق افضل انجاز بهدف الحصول على النقاط الفنية او لتثبيت الخصم على كتفيه وتحقيق الفوز • عند تعليم أي حركة فنية (مسكة) وبغض النظر عن درجة صعوبتها ينبخي اتباع القواعد التربوية( من السهل الى الصعب) من البسيط الى المعقد (المركب) ويكون ذلك باداء الحركات منفردة في لعبة المصارعة. كما ان الاداء الفني للمسكات يعتمد على النوافق الحركي والتوافق عبارة عن ايجاد علاقة حركية متجانسـة مبنيـة على التوقيت الصحيح بين اجزاء معينـة من المجاميع العضلية بمـا ينسجم والاقتصـاد بالجهد وسـولة الاداء للوصول الى نتائج هادفة من خلال تتظيم مجدي لاستخلال التأثنر المتبادل بين القوى الداخلية والخارجية" مما لاشك فيهه ان الاعداد لـلأداء الفني (للمسكات) المتتوع والثـامل واحد من اهم متطلبات المستوى في لعبـة المصـارعة" (

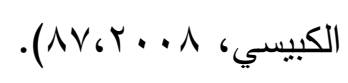

إن الأداء الفنـي الصـيح والدقيق للمهارة معنـاه التكنيك وهي صـفة مميزة لانـواع المهارات" التكنيك هـو

التصرف الدقيق للمهارة وهي حالة المرء الفنية التي تثمل الاداء كله" (محجوب، 910 (، ؟ ـ (). وفي لعبة المصارعة يعتبر تحسين وتثنيت الاداء الفني للمهارة (المسكة) المعينة المحتوى الرئيس في عملية

$$
\text { التعلم والتدريب الرباضي. }
$$

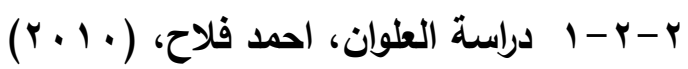
(أساليب التعلم المفضلة لدى طلبة المدارس الثانويـة في مدينة معان في الاردن وعلاقتها بمتغيري الجنس

والتخصص الأكاديمي)

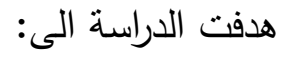

- التعرف الى اساليب التعلم المفضلة لدى طلبة المدارس الثانوية. - معرفة مدى اختلاف هذه الاساليب باختلاف الجنس والتخصص الأكاديمي.

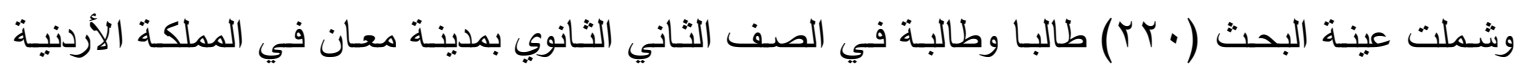
الهاشـمية جرى اختيارهم بالطريقة الطبقيـة العشوائية لتشكل (•r\%) من مجتمـع الدراسـة، كي تكون ممثلة لمجتمـع الدراسة، إذ جرى اختيار ما نسبته (•r\%) من الطلبة الذكور في التخصص العلمي وبلغ عددهم (Yr) طالبا وجرى اختيار ما نسبته (•r\%) من الطلبة الذكور في التخصص الأدبي وبلغ عددهم (vo) طالبا، كما جرى اختيار ما نسبته (•r\%) من الطالبات الإنات في التخصص العلمي وبلغ عددهم (^^) طالبة وتم اختيار ما نسبته (•r\%) من الطالبات الإناث في التخصص الأدبي وبلغ عددهم (90) طالبة. وقد أسفرت النتائج عن ما يأتي: 
- - أكثر اسـاليب التعلم تفضيلا لدى الطلبة هي: السمعي، يليـه البصري، وان اقل الاسـاليب تفضيلا هي اسلوب التعلم اللمسي. - وجود فروق ذات دلالة إحصائية في اساليب التعلم المفضلة تعزى الى متغير التخصص الأكاديمي، حيث فضل طلبة الفرع العلمي اساليب التعلم البصرية واللمسية في حين فضل طلبة الفرع الادبي اسلوب التعلم السمعي.

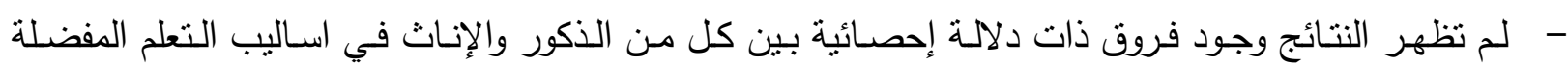

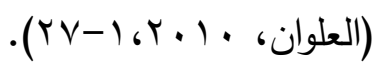

$$
\begin{aligned}
& \text { r- منهج البحث }
\end{aligned}
$$

استخدم الباحثنان المنهج التجريبي لملاءمته لعينة البحث.

$$
\text { r- 1 - 1 مجتمع البحث وعينته }
$$

تم اختيار مجتمع البحث بالطريقة العمديه متمثلة بطلبة السنة الدراسية الثالثة بكلية التربية الرياضية بجامعة

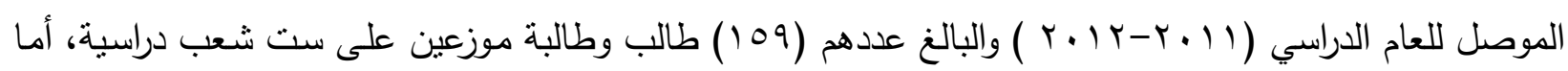
عينة البحث فتكونت من ثلاث شعب دراسية نم اختيارها بصورة عثوائية وهي (ب، هـ، و) وبعد ان حدد الباحثان مجتمع وعينة البحث تم استبعاد الطالبات والطلاب الراسبون وتاركوا الدراسـة وممن لديهم خبرة في لعبة المصارعة لتحقيق مبدأ التكافؤ والتجانس في المجاميع التجريبية، وبغية تكوين مجموعات البحث الست قام الباحثان بتحديد التفضيلات الحسية اعتمادا على قائمة التفضيلات الحسية والمعدة من قبل الباحثان من اجل تطبيقه وبما يلائم البيئة العراقية وبلغ عدد فقرات القائعة بصورتها النهائية (Y) فقرة ملحق ( ())، وبعد الإجابة عن أسئلة القائمة من قبل عينة البحث وبعد جمعها وتفربغ الاستمارات وتفسير الدرجات حصلنا على الطلاب ذوي التضضيل (البصري، السمعي، اللمسي) وتم اختيار فئة وزن (ع Vكغم) بالطريقة العددية وتوزيع الفئة الوزنية المختارة الى سـ مجاميع تجريبيـة، إذ كانت كل مجموعتين تجريبيتين في شـعبة دراسية واحدة وبواقع اربعة طـلاب لكل مجموعة، ثناث مجموعات تجريبية تمارس بفئات وزنية مختلفة وثلاث مجموعات تجريبية تمارس مـع الفئة الوزنية نفسها على وفق التفضيل الحسي. 
استخدم الباحثنان التصميم التجريبي الذي يطلق عليه (تصميم المجموعات المتكافئة ذات الملاحظة البعدية)

(Best, 1970,150) والثكل ( ) يوضح ذللك

\begin{tabular}{|c|c|c|}
\hline الاختبار & المتغير المستقل & 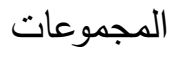 \\
\hline 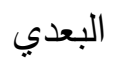 & اسلوب تفضيل التعلم البصري+ فئات وزنية مختلفة & ت \\
\hline 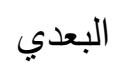 & أسلوب تفضيل التعلم البصري + نفس الفئة الوزنية & r \\
\hline 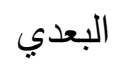 & أسلوب تفضيل التعلم السمعي + فئات وزنية مختلفة & 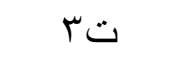 \\
\hline 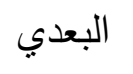 & أسلوب تفضيل التعلم السمعي + نفس الفئة الوزنية & $\varepsilon$ \\
\hline 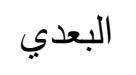 & أسلوب تفضيل التعلم اللمسي + فئات وزنية مختلفة & ت \\
\hline 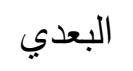 & أسلوب تفضيل التعلم اللمسي + نفس الفئة الوزنية & ت \\
\hline
\end{tabular}

تتطلب الدراسة الحالية قياس التفضيلات الحسية لعينة البحث وبعد اطلاع الباحثان على المصادر والأبحاث

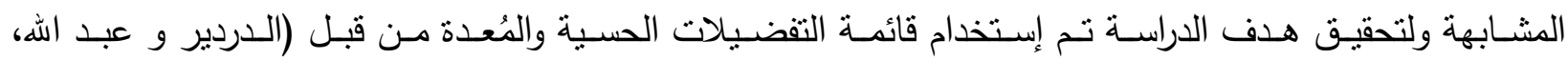

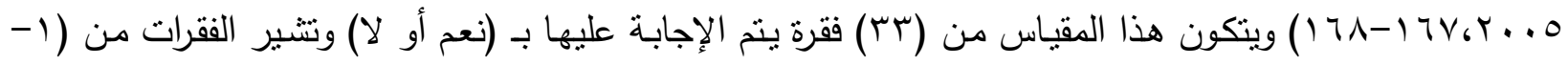

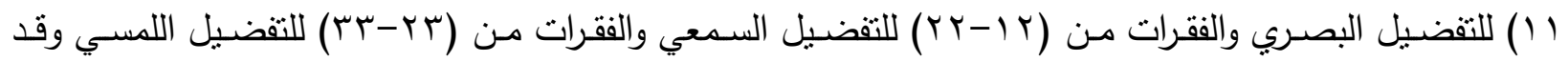
أُجريت مجموعة من الاجراءات العلمية لإعداد هذا المقياس لتطبيقه في المجال الرياضي وبما يُلائم البيئة العراقية من دون الخروج عن أساسيات بناء المقياس من حيث الجوهر . r-r - r- الأسس العلمية للمقياس

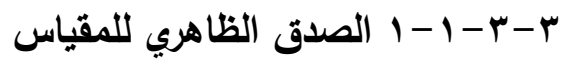
"الصدق الظـاهري هو الاختبار الذي يدل اسمه على صدقه، اي صـادق في صسورته الظـاهرة" (فرحسات،

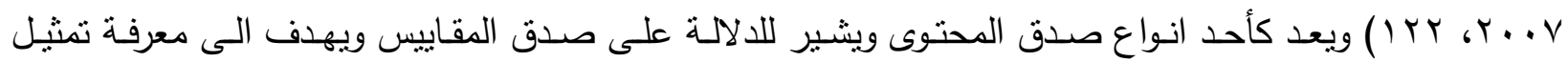

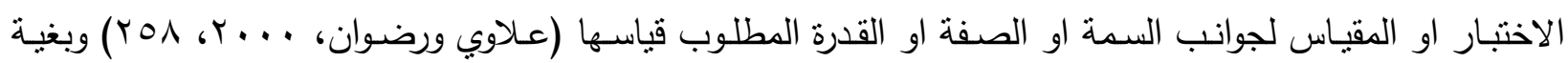
الحصول على صدق المقياس تم عرضـه على عدد من المختصين في مجال العلوم النفسية والتربوية وعلم النفس الرياضـي ملحق (ع) للتأكد مـن صـلاحية فقرات المقيـاس البـالغ (rس) فقرة وقد إتققت الاراء على اجـراء بعض التعديلات في اسلوب صياغة بعض الفقرات والتي أخذ بها الباحثان وبدرجة اتفاق تزبد عن ( •^\%) لكل فقرة من 
فقرات المقياس "على الباحث ان يحصل على نسبة اتفاق للخبراء في صـلاحية الفقرات وبامكان اجراء التعديلات

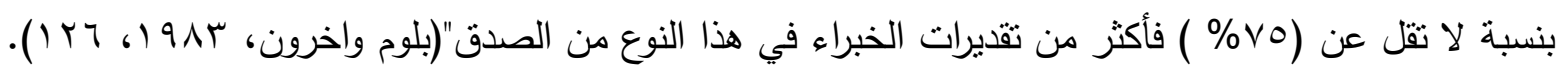
r-r وتم تحقيقه من قبل الباحثان في اتجاهين: r-r

تتوافر في المقياس الحالي احد مؤشرات صدق البناء إذ بعد تطبيق المقياس على ( . . ( ) طالب من غير طلاب عينة البحث وبعد تفريغ الاستمارات تم تجميع البيانات ومعالجتها باستخدام (معامل ارتباط بيرسون) وذلك لإيجاد الارتباط بين درجة كل فقرة من الفقرات والدرجة الكلية على المقياس " تعد معاملات الارتباط بين درجة كل

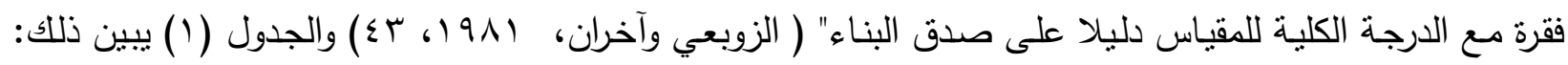

جدول (1)

يبين معامل الاتساق الداخلي للفقرات

\begin{tabular}{|c|c|c|c|c|c|c|c|c|c|c|c|}
\hline معامل الارتباط & رقم & معامل الارتباط & رقم & معامل الارتباط & رقم & معامل الارتباط & رقم & معامل الارتباط & رقم & معامل الارتباط & رقم \\
\hline דו & I & $\cdot, 10 \leqslant$ & ro & $* \cdot, r q \mu$ & 19 & $*, \pi \mid V$ & ir & * $\cdot$ r, qV & v & $*, \Upsilon \wedge \wedge$ & 1 \\
\hline ו & rr & $*, Y \wedge I$ & YT & ק & $r \cdot$ & * & $1 \varepsilon$ & * $\cdot$, Y & $\wedge$ & $* \cdot, \varepsilon V \cdot$ & $r$ \\
\hline \multirow[t]{4}{*}{$\cdot, \mid \wedge \varepsilon$} & rr & $*, \leqslant 7 V$ & rV & $\cdot, 1 v_{0}$ & rl & * & 10 & $* \cdot r V r$ & 9 & $* \cdot, 0 \leq 7$ & r \\
\hline & & * & r^ & $* \cdot, Y \circ V$ & rY & $* \bullet,\{r$. & 17 & $\cdot, \cdot \leq \leqslant$ & 1. & $\cdot, 17 \varepsilon$ & $\varepsilon$ \\
\hline & & $* \cdot r V \cdot$ & rq & $\approx \cdot, r q \wedge$ & r & 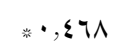 & IV & $\cdot, 191$ & 11 & $* \cdot 0.7$ & 。 \\
\hline & & $*, r 90$ & $r$. & 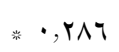 & rq & $*, Y Y \Lambda$ & 11 & 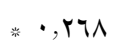 & ir & $* \cdot, \varepsilon r q$ & 7 \\
\hline
\end{tabular}

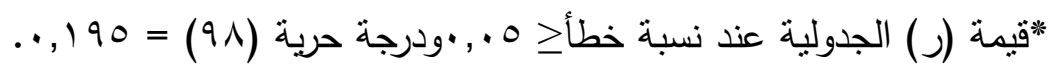

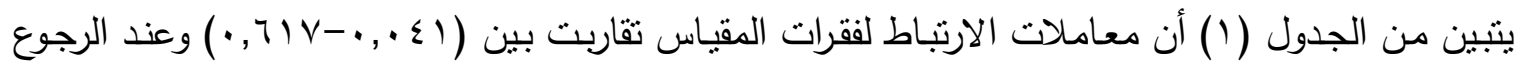

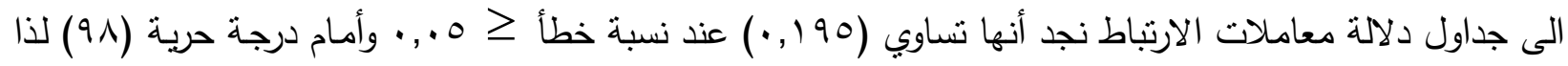

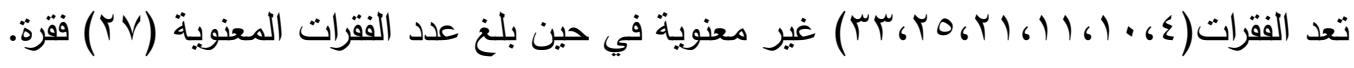
ب-r-1 - القوة التمبيزية للفقرات

إن معامل التمييز بين المجموعتين العليا والدنيا يقبس قوة تمييز كل فقرة حيث قام الباحثان باستخدام أسلوب المجموعتين المتضـادتين العليا والدنيا وتم ترتيب البيانات ترتيبا تصاعديا على وفق بيانات الاتساق الداخلي لفقرات 


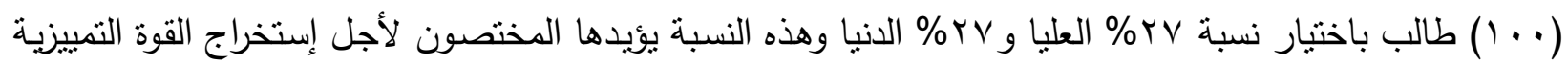
للفقرات، والجدول (r) يبين ذلك بلك

جدول (r)

يبين القوة التمييزية للفقرات

\begin{tabular}{|c|c|c|c|c|c|c|c|c|c|c|c|}
\hline المحسوبة & رقم & المحسوية & رقم & المحسوية & رقم & المحسوية & رقم & المحسوبة & رقم & المحسوية & رقم \\
\hline $1, \vee \wedge 1$ & וr & --- & ro & $1,1 \vee 0$ & 19 & $* \vee, 070$ & M & *T,YY. & V & * & 1 \\
\hline$* Y, Y V Y$ & Mr & *T, हाT & $r t$ & $1, \varepsilon 9 V$ & $r$. & *Y,VYI & $1 \leq$ & $1, \cdot r$. & $\Lambda$ & * & $r$ \\
\hline \multirow[t]{4}{*}{---} & rس & $* \varepsilon, \varepsilon 10$ & Tr & --- & ri & $* r, \mid r)$ & 10 & *ฯ, ११ & 9 & $* 0,11 \wedge$ & $r$ \\
\hline & & $* 0, \cdot A r$ & r^ & $1 . .+0$ & r & $* \varepsilon, 01 Y$ & 17 & --- & 1. & --- & $\varepsilon$ \\
\hline & & ש & rq & *Y,O & r & $* 0,111$ & IV & --- & 11 & $* 0, \cdot \wedge r$ & o \\
\hline & & $* Y, 0 \leqslant \wedge$ & $r$. & $1,91 \mathrm{~V}$ & $r \varepsilon$ & $* \Psi, \varepsilon \vee \varepsilon$ & 11 & $* Y, Y \wedge O$ & Ir & $* r, q T V$ & 7 \\
\hline
\end{tabular}

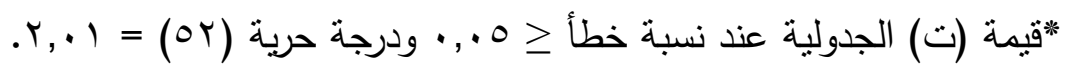

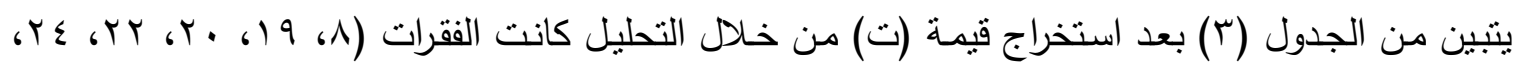

آT) غير معنوية كون قيم (ت) المحسوبة اصغر من قيمة (ت) الجدولية عند مستوى معنوية (0. . ) ودرجة حرية

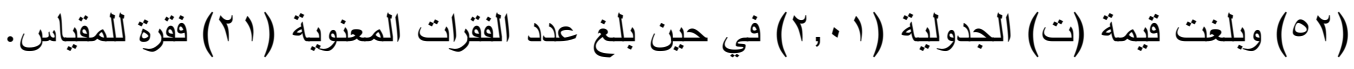

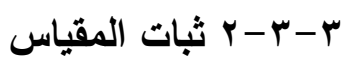

إن الثبات يعني الاتساق في مجموع درجات فقرات المقياس التي يفترض أن يقيس ما يجب قياسه إذا ما

تكرر إعادة تطبيقه على العينة نفسها تحت الثروط أو الظروف نفسها والاتساق يكون على نوعين هما:

- - إعادة الاختبار (الاتساق الخارجي).

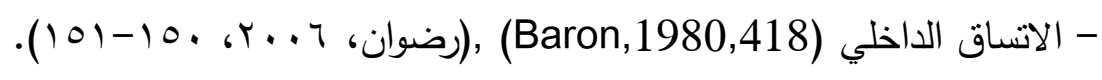

r-r-r-1 - ب إعادة الاختبار (الاتساق الخارجي)

تم استخراج الثبات عن طريق إعادة الاختبار إذ تم تطبيق الأداة على طلاب وعددهم (؟ ه) طالب من غير

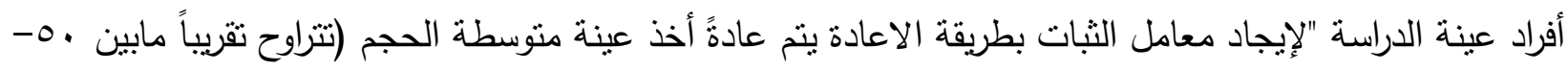

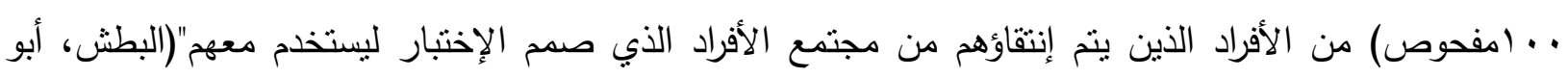

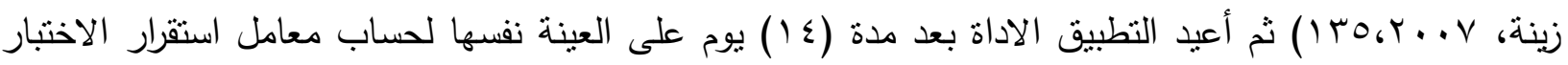

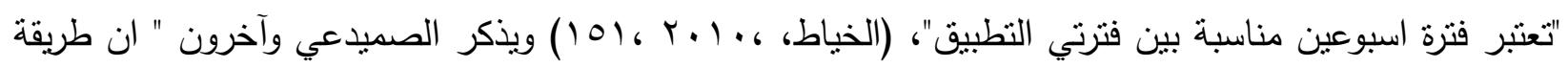


اعادة الاختبار هي الطريقة التي يستخدم فيها إجراء الاختبار لمرتين بفاصل زمني مناسب تحت نفس الظروف

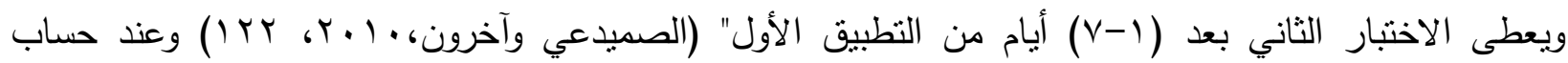

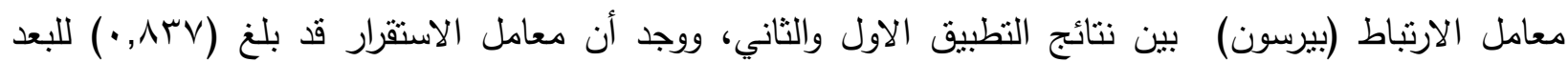

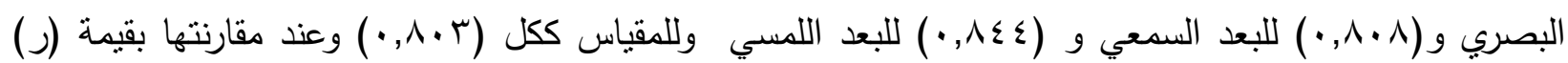
الجدولية والبالغة (سVT, • ) إستدل من ذلك وجود علاقة معنوية مما يعني أن الأداة تتمتع بدرجة عالية من الثبات. r-r r-r r r r r الاتساق الاخلي إذا كانت الدرجة على الفقرات المكونـة للإختبار ثنائية فيتم إيجاد معامل الثبات بإستخدام معادلة كيودر -

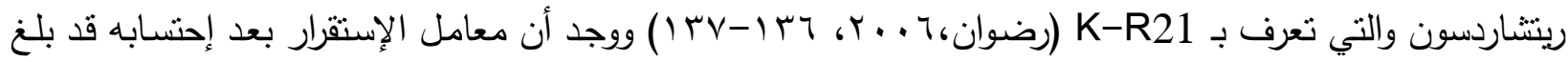

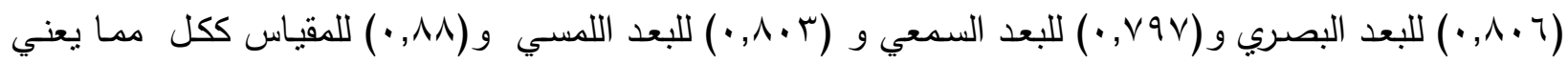
أن الأداة تتمتع بدرجة عالية من الثبات.

r-r-r r-r صورة المقياس النهائية

بعد الانتهاء من تحليل الفقرات والتأكد من صدق وثبات المقياس تم إعداد الصيغة النهائية ملحق ( () وبلغ عدد فقراته (Y) فقرة ببدائل اثتين (موافق و غيرموافق) "بستخدم أسلوب الإجابة (موافق و غيرموافق) في الأسئلة التي تقيس خصائص او سمات تتخيصية أو ابعاد مختلفة" (فرحات، V. . Y، 9 ؛) وتوزعت الفقرات على ثلاثة أبعاد كالأتي: البعد الأول (V) فقرات تمنل التضيل البصري وهي من ( ( V- فقرات. البعد الثاني (V) فقرات تمثل التفضيل السمعي وهي من (^-ع ( ) فقرة. البعد الثالث (V) فقرات تمثل التفضيل اللمسي وهي من (10-1 (Y) فقرة. وبذلك تكون الدرجة الكلية للمقياس (Y) درجة " فإذا حصلت على درجة مرتفعة في إحدى التفضيلات الثثلاثة (البصري، السمعي، اللمسي) فهذا يدل على انك تفضل هذه الحاسة في مواقف التعلم"، (الدردير وعبد الله، $.(1) \wedge, 1+.0$ r-r-r - r - إجراء قياس التفضيلات الحسية تم إجراء قياس التفضيلات الحسية على عينة البحث في يوم الثلاثاء الموافق \&/ • /1 1 • ب وبعد الإجابة عن المقياس من قبل عينة البحث لنحصل على الطلاب ذوي التفضيل (البصري، السمعي، اللمسي) وتم توزيعهم الى ثلاث مجاميع وبواقع ثمان طلاب لكل تفضيل ثم تم تقسيم كل مجموعة الى (ع) طلاب بصورة عشوائية ليكون عدد المجاميع التجريبية ستة مجاميع باعتماد فئة وزن (ع V)كغم بصورة عمدية من اجل تحقيق هدف وفرض البحث. r- بـ تكافؤ مجموعات البحث تم إجراء التكافؤ بين مجموعات البحث في العمر الزمني مقاسا بالأشـهر والطول مقاسـا بالسنتيمنز والكتلة مقاسه بالكيلوغرام وتبين وجود فروق ذات دلالة غير معنوية بين طلاب المجاميع الست لعينة البحث بتلك المتغيرات 
والتكافؤ في بعض عناصـر اللياقـة البدنية والحركية المؤثزة في تعلم الاداء الفني لبعض مسكات المصـارعة الحرة وحددت الاختبارات استتاداً لرأي الخبراء والمختصين في مجال التعلم الحركي وطرائق التدريس ولعبة المصارعة ملحق (ع) ورشحت عناصر اللياقة البدنية والحركية واختباراتها المختارة بعد أن تم وضعها في صورة استبيان ملحق (r) وحددت الاختبارات التي تقيس هذه العناصر من قبل الخبراء والمختصين ذاتهم واختصرت على العناصر الخمسـة الأكثر تكراراً واختباراتها المختارة كالآتي: - - القوة الانفجارية للأطراف العليا: تم قياسها باختبار رمي الكرة الطبية زنة (0) كغم لأبعد مسافة ممكنة من وضع الجلوس على كرسي من الثبات لأبعد مسافة مدكنة (عثمان، . 199 (1)، بس ). - القوة الانفجاريـة للأطراف السفلى: قوة عضـلات الظهر (القوة القصوى الثابتة): تم قياسـها باختبار قوة عضـلات

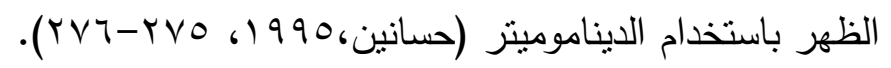

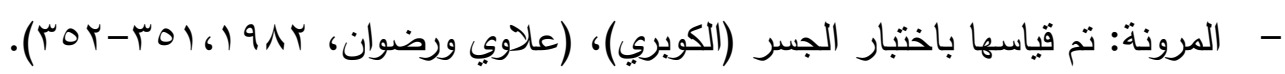

- - القوة المميزة بالسرعة لعضلات الذراعين: تم قياسـها باختبار الاستتاد الامـامي ثتي ومد الذراعين باستقرار لمدة

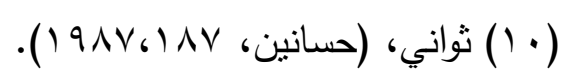

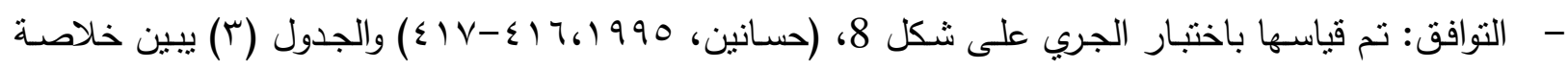
تحليل التباين لمجاميع البحث الست في اختبارات عناصر اللياقة البدنية والحركية المختارة.

$$
\text { الجدول (r) (ب) }
$$

\begin{tabular}{|c|c|c|c|c|c|c|c|}
\hline 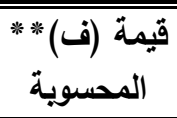 & متوسطات & الحرية & المربعات & مصدر التباين & القياس & المتغيرات & $ت$ \\
\hline \multirow{2}{*}{1,11} & $\cdot, 1 \cdot 1$ & $\bullet$ & $\cdot, 0 \leq r$ & بين المجموعات & \multirow{2}{*}{ 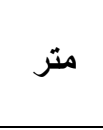 } & \multirow{2}{*}{ رمي الكرة الطبية زنة (•) كغم } & \multirow{2}{*}{-1} \\
\hline & $\cdot, .9 V$ & 11 & $1, V Y r$ & داخل المجموعات & & & \\
\hline \multirow[b]{2}{*}{$\cdot, £ \wedge$} & $\uparrow, \ldots$ & 0 & $r \cdot, r$ & بين المجموعات & \multirow[b]{2}{*}{ كفم } & \multirow{2}{*}{ قوة عضلات الظهر باستخدام } & \multirow[b]{2}{*}{$-r$} \\
\hline & Ir,V & 11 & $\curlyvee \wedge \wedge, \wedge$ & داخل المجموعات & & & \\
\hline \multirow{2}{*}{1,94} & $|r \cdot|$, & ○ & $\neg \cdots, V$ & بين المجموعات & \multirow{2}{*}{ سم } & \multirow{2}{*}{ اختبار الجسر (القوس) } & \multirow{2}{*}{$-r$} \\
\hline & TY,Y & 11 & $11 r \cdot r$ & داخل المجموعات & & & \\
\hline \multirow{2}{*}{. , $9 \varepsilon$} & r,IV & 0 & $1 \cdot, \wedge \wedge$ & بين المجموعات & \multirow{2}{*}{ 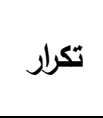 } & \multirow{2}{*}{ اختبار الاستتاد الامامي (· ثاني } & \multirow{2}{*}{$-\varepsilon$} \\
\hline & r,rr & 11 & $\leqslant 1, \vee 0$ & داخل المجموعات & & & \\
\hline \multirow{2}{*}{$\cdot, r q$} & $\cdot, Y_{1} \cdot$ & 0 & $1, \cdot \leq 9$ & بين المجموعات & \multirow{2}{*}{ ثانية } & \multirow{2}{*}{ اختبار الجري على شكل 8} & \multirow{2}{*}{-0} \\
\hline & $\cdot, 0 \leq r$ & 11 & $q, v \circ v$ & داخل المجموعات & & & \\
\hline
\end{tabular}

يبين نتائج تحليل التباين بين مجموعات البحث في بعض اختبارات اللياقة البدنية والحركية المؤثرة في تعلم الاداء الفني

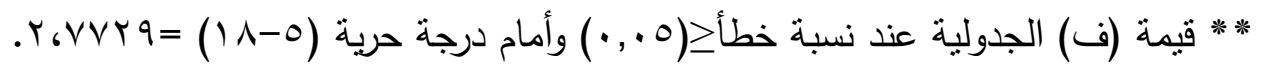


يتبين من الجدول (ب) وجود فروق ذات دلالـة غير معنويـة بين طـلاب المجاميع الست لعينـة البحث في متغيرات (اختبارات عناصر اللياقة البدنية والحركية) إذ كانت قيمة (ف) المحسوبة اصنغر من قيمة (ف) الجدولية مما يدل على تكافؤ عينة البحث في تلك المتغيرات. ب-ه البرامج التعليمية إعتمد في إعداد البرنامج التعليمي على مفردات المهارات الحركية لمادة المصـارعة للفصل الدراسي الأول

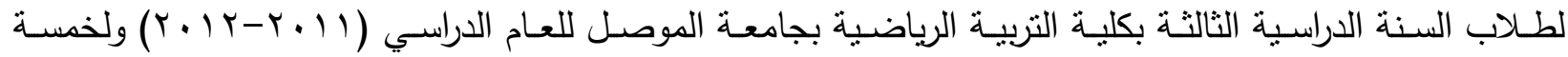
مهارات حركية (مسكة الرمي بحجز الرأس والذراع، مسكة التقاط كاحل القدم، مسكة الدوران بربط الخصر، مسكة

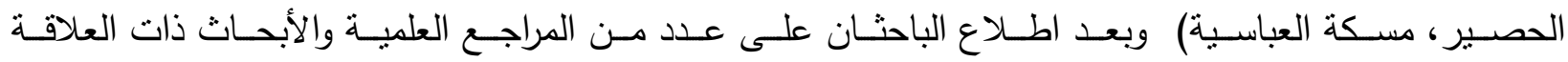

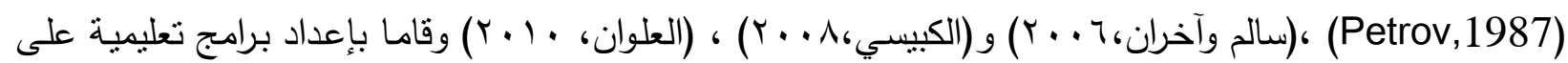
وفق التفضيلات الحسية (البصـرية، والسـمعية، واللمسية) للجزء الرئيس مـن الوحدة التعليميـة، بعد أن يتم توزيـع الطلاب بشكل ثثائي إذ مارس طلاب المجاميع التجريبية الثلاث (ت ا، ت ب، ته) مع فئات وزنية مختلفة للأوزان

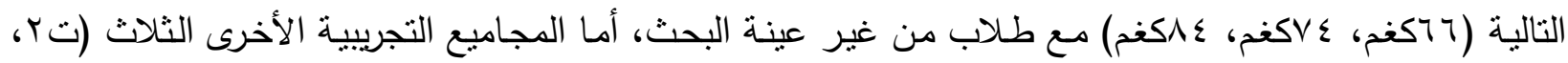
تـ، ت 7) فمارست المهارات الحركية ذاتها مـع الفئة الوزنيه نفسها للطلاب وهي (ع Vكغم) من غبر عينـة البحث، ومن اجل توحيد التكرارات بين مجاميع البحث قام الباحثان بإجراء تجربة استطلاعية على (·rطالب) من غير عينة الدراسـة بتاريخ هץ-ع - 1 1 ـ ـ على طلاب السنة الدراسية الثالثة في كلية التربية الرياضية بجامعة الموصل وتبين بان متوسط التكرارات لمهارتين حركيتين بلغ (ع ع) تكرار وبزمن أداء بلغ (Yr)د وتصحيح أخطاء ( • ()ـ وبزمن راحة بلـغ (ع) بد بعد أن أعطى زمن شـرح لكل مسكة (0) دقائق على وفق كل تفضيل حسي وبذللك يكون زمن الجزء التطبيقي († ؛)د، وبعد ان تأكد الباحثان من امكانية وملائمـة البرامج التعليميـة على وفق كل تفضيل قام الباحثان بإعداد وحدات تعليميـة ملحق (r) وتحقق من صـلاحيتها من خـلال عرضـها على عدد من المختصين ملحق(ع) وحصلت على نسبة إتفاق تزيد عن •^^\% ثم تم تطبيقها من قبل مدرس مادة المصارعة* بعد اطلاعه عليها للفترة

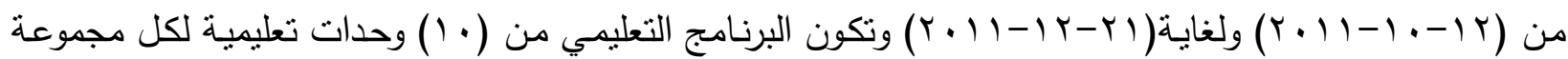
ولفترة عشرة أسابيع وبواقع وحدة تعليمية واحدة لكل مجموعة في الأسبوع وزمن الوحدة التعليمية ( • (ه). r- r r تقويم فن الاداء. تم التقويم بواسطة ثلاث مقومين من ذوي الخبرة والاختصاص في لعبة المصارعة لصعوبة جمع المقومين الثلاث في يوم واحد ملحق(ء) واستخدم كل منهم استمارة تقويم بعد ان تم عرضـها على ذات المختصين للتحقق من صدقها بعد أن حددت الدرجة الكلية بعشرة درجات لكل مسكة ملحق(ه) لتقوبم المهارات. 
لتقويم المهارات الحركية لعينـة البحث، وبهدف التأكد من موضعية التقويم بين المقومين تم اختيار إحدى المهارات الحركيـة بصدورة عشوائية فكانت (مهارة الدوران بربط الخصـر) وتم حسـاب معامل الارتباط المتعدد بين

درجات المقومين التثلاث فكانت نتيجة الارتباط (10, 10, ) وهو معامل ارتباط عالي في تقويم المهارات الحركية ويتضـح من ذلك أن عملية التقويم كانت موضوعية " إن الاختبار إذا ما جرى وعرض على مجموعة من

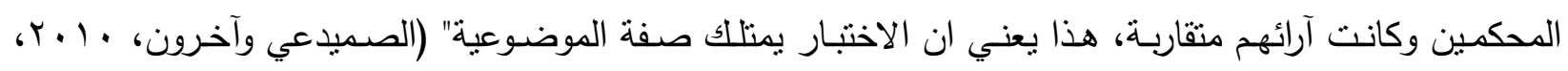

rالوسط الحسابي، الانحراف المعباري، معامل الارتباط المتعدد، معامل الارتباط البسبط، اختبار "ت" لوسطين حسابيين غير مرتبطين متسـاويين بالعدد، (التكريتي والعبيدي، 999 1، 1 ـ 1- ـ (ب)، معادلة كيورد- ريتشاردسون

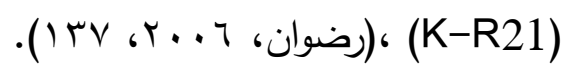
ع -عرض ومناقشة النتائج ع - 1 عرض ومناقشـة نتائج اختبار(ت) بين المجموعتين التجريبيتين (البصرية) الأولى والثانية في تعلم الاداء الفني لبعض مسكات المصارعة الحرة جدول (๕)

بيين نتائج اختبار (ت) للاختبارات البعدية للمجموعة البصرية للطلاب الذين تعلموا مع الفئة الوزنية نفسها و بفئات وزنية مختلفة للأداء الفني للمهارات التي تضمنها البرنامج التعليمي

\begin{tabular}{|c|c|c|c|c|c|c|c|}
\hline \multirow[t]{2}{*}{ قيمة (ت) } & \multicolumn{2}{|c|}{ بنفس الفئة الوزنية الذين تعلما } & \multicolumn{2}{|c|}{ الطلاب الأين تعلموا } & \multirow[t]{2}{*}{ وحدة القياس } & \multirow[t]{2}{*}{ المعالم الاحصائية } & \multirow[t]{2}{*}{$ت$} \\
\hline & $\varepsilon^{ \pm}$ & 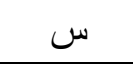 & $\varepsilon^{ \pm}$ & س & & & \\
\hline$* ץ, \neg 7 \wedge$ & $\cdot, 0 \ldots$ & $7 . Y 0$. &., $1 Y 0$ & $7,9 \mu \mathrm{V}$ & درجة & مسكة الرمي بحجز الرأس والذراع & -1 \\
\hline$* Y, T \leq 7$ & r & $7, r \vee 0$ &., $0 \ldots$ & $V, Y O$. & درجة & مسكة التقاط كاحل القدم & $-r$ \\
\hline$* r, \cdot r$ & $\cdot, \Sigma \vee \wedge$ & 7, rVo & $\cdot, r r q$ & $\vee, 1 \wedge V$ & درجة & مسكة الدوران بربط الخصر & r \\
\hline$* Y, Y \leq 7$ & $\cdot, 1 \leq \varepsilon$ & $7, \wedge \vee 0$ & $\cdot, 7 \leqslant 0$ & $\vee, \vee O$. & درجة & مسكة الحصير & $-\varepsilon$ \\
\hline$* \varepsilon,+1 r$ & $\cdot, \vee \backslash \wedge$ & $7, \cdot 7 r$ & $\cdot$, rvo & $V, 7 \wedge \mathrm{V}$ & درجة & مسكة العباسية & -0 \\
\hline
\end{tabular}

بلغت قيمة (ت) المحسوبة للمهارات الاتية (مسكة الرمي بحجز الرأس والذراع، مسكة التقاط كاحل القدم،

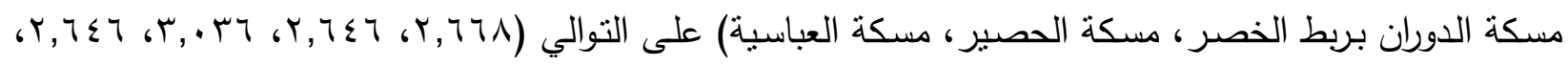

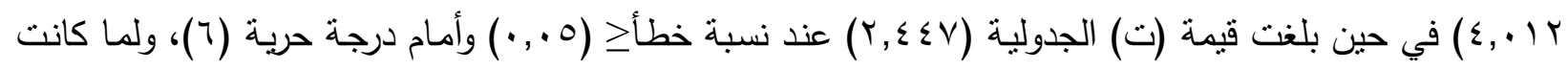


قيمـة (ت) المحسوبة اكبر مـن قيمـة (ت) الجدوليـة، فهذا يعنـي وجـود فروق ذات دلالـة معنويـة ولصـالح طـلاب المجموعة البصرية اللذين تعلموا بفئات وزنية مختلفة. في ضوء النتائج التي تم التوصل اليها في الجدول (ع) تبين وجود فروق ذات دلالة معنوية في الاختبارات البعديـة بين طـلاب المجموعة البصرية اللذين تعلموا الفئة الوزنيـة نفسها وطـلاب المجموعة البصرية اللذين تعلموا بفئات وزنية مختلفة، ويمكن القول أن المجموعة البصرية التي تعلمت مع فئات وزنية مختلفة كانت المجموعة الأكثر تطوراً في فن الاداء المهاري للمهارات الحركية الخمس التي تضمنها البرنامج التعليمي، إذ ساهم إستخدام التضضيل البصري في تعزيز عملية التعلم للاداء الفني للمهارة وتثيتها أو تعديلها بالإتجاه الصحيح لكلتا المجموعتين بالرغم من الفروق المعنوية بينهما، إذ أن تقديم المعلومات عن طريق العرض الأنموذجي ساعد على تطور النشاطات التعليمية لملاحظة تفاصيل المهارة مما أعطى صورة كاملة وواضحة عن طبيعة المسار الحركي وإنعكس ذلك بشكل ايجابي لمجموعتي البحث البصريتين إذ يذكر الخياط، "أن المتعلم دائم التشوق لروئية كل جديد من الحركات التي يعرضها المعلم لغرض تعلمها، فمها بلغت دقة الوصف اللفظي أو الثرح لايمكن بأي حال من الأحوال أن يعوض المتعلم عن رؤية الأنموذج الخاص بالحركة، أن عملية التعلم ترتبط إرتباطا وثثقاً بالصورة المرئية الحقيقية" (الخياط، ؟ . . ؟ ، 10) كما أن تفوق المجموعة البصرية التي مارست الاداء بفئات وزنية مختلفة على المجموعة البصرية التي مارست الاداء بفئات وزنية منساوية كان نتيجة تتظيم وتتوع أثنكال التمرينات بتتوع إستخدام الفئات الوزنية من خلال الممارسة والتكرار مـع فئات وزنية أقل سهل عملية تعلم الاداء الفني وتثبيت الاداء القائم على الممارسـة الصحيحة والتعلم مع اهع نفس الفئة الوزنية أعطى صورة واضحة لـلاداء المطلوب تتفيذه خلال الصراع فضـلاً عن التعلم مع فئات وزنية أكبر سهل عملية التعلم من خلال رفع الروح المعنوية نتيجة التكرار القائم على أساس الممارسة الصحيحة وهذا ما يؤكدهُ حسام الدين واخرون، "إن ضرورة التتوع في استخدام التمرينات او اسلوب ادائها حيث ان من اكثر الاخطاء التدريبية انتشارا بين المدربين هو اغفال عملية التغيير في الاثار التدريبية من هذه التغيرات مثنا الغيير في عدد التكرارات او عدد المجموعات او من خلال شدة الحمل المستخدم او في سرعة اداء التمرين وفترات الراحة" (حسام الدين واخرون، $\cdot($ or 6 . .11 
צ - Y عرض ومناقثـة نتائج اختبار(ت) بين المجموعتين التجريبيتين (السمعية) الثالثة والرابعة في تعلم الاداء

الفني لبعض مسكات المصارعة الحرة

جدول (0)

يبين نتائج اختبار (ت) للاختبارات البعدية للمجموعة السمعية للطلاب اللذين تعلموا مع الفئة الوزنية نفهها

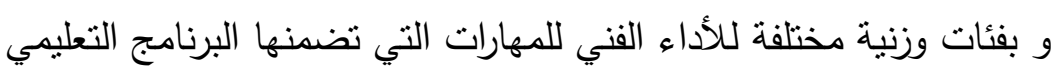

\begin{tabular}{|c|c|c|c|c|c|c|c|}
\hline \multirow[t]{2}{*}{ قالمحسو (ت) } & \multicolumn{2}{|c|}{ بنفس الفئة الوزنية تعلموا } & \multicolumn{2}{|c|}{ بفئات وزنية مختلفة الذين تعلموا } & \multirow{2}{*}{ القياس } & \multirow{2}{*}{ آلمعللم الاحصائية } & \\
\hline & $\varepsilon \pm$ & 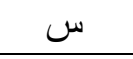 & $\varepsilon \pm$ & 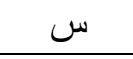 & & & \\
\hline$* Y, \Sigma V Y$ & $\cdot, 1 r_{0}$ & $0,9 \mu \mathrm{V}$ & $\cdot, 7 \leqslant 0$ & $7, \vee 0$. & درجة & مسكة الرمي بحجز الرأس والذراع & -1 \\
\hline$*$ *, $9 \vee$. & . זrq & $0, M, r$ & $\cdot, \varepsilon \vee \wedge$ & 7, rVo & درجة & مسكة التقاط كاحل القدم & $-r$ \\
\hline$* r, \vee \vee q$ & $\cdot$, YO. & $0, \wedge \vee 0$ & $\cdot, \leqslant Y \uparrow$ & $7,07 r$ & درجة & مسكة الدوران بربط الخصر & $-r$ \\
\hline$* r, O V T$ & $\cdot, \vee \vee \wedge$ & $0, \varepsilon \Gamma V$ & $\cdot, \varepsilon \cdot \Lambda$ & $7,0 \ldots$ & درجة & مسكة الحصير & $-\varepsilon$ \\
\hline$* r, 700$ & $\cdot, Y \wedge \wedge$ & $0, Y 0$. & $\cdot, \vee \vee \leqslant \neg$ & $7, \Gamma) r$ & درجة & مسكة العباسية & -0 \\
\hline
\end{tabular}

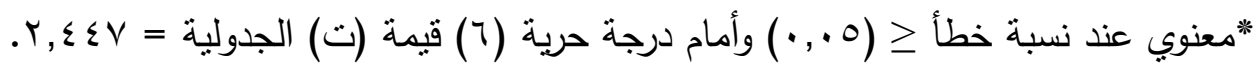

يتبين من الجدول (0) ما يأني:

بلغت قيمة (ت) الحسوبة للمهارات الاتية (مسكة الرمي بحجز الرأس والذراع، مسكة التقاط كاحل القدم،

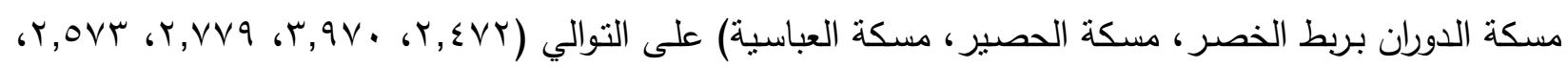

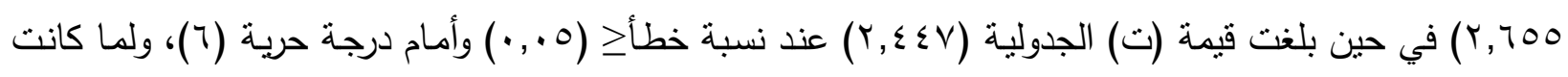

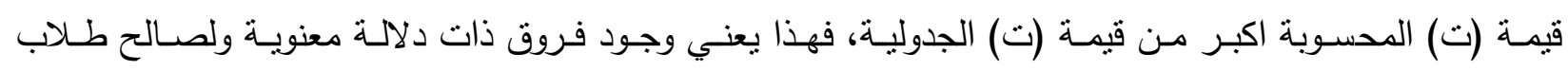
المجموعة السمعية اللذين تعلموا بفئات وزنية مختلفة. في ضوء النتائج التي تم التوصل اليها في الجدول (0) تبين وجود فروق ذات دلالة معنوية في الاختبارات البعدية بين طلاب المجموعة السمعية الذين تعلموا بنفس الفئة الوزنية وطلاب المجموعة السمعية اللذين تعلموا بفئات وزنية مختلفة، ويمكن القول أن المجموعة السمعية التي تعلمت مع الفئة الوزنية نفسها كانت المجموعة الأقل تطوراً

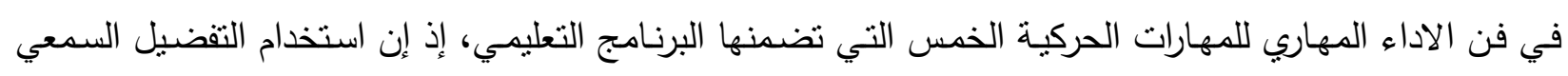

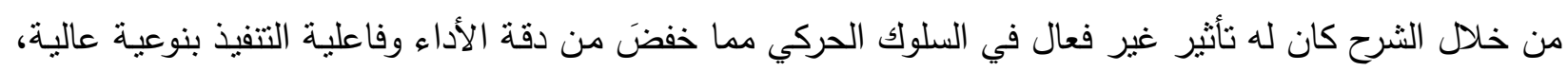

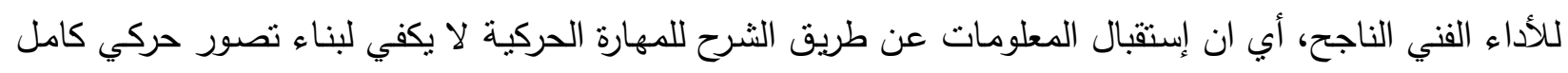

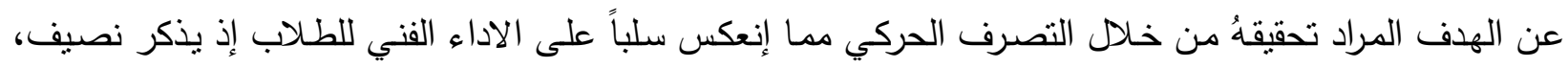

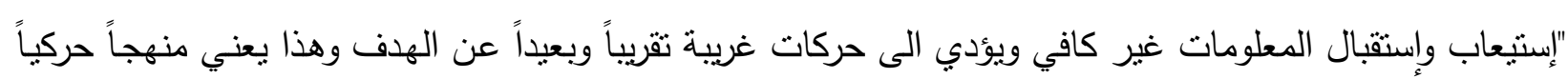

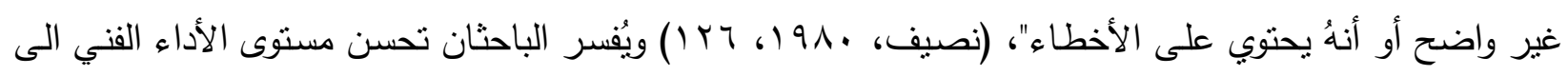
قدرة المتعمين من الإستفادة من التحكم الداخلي مما سهل عملية تعلم المسكات عن طريق ممارسة التكرارت للمهارات 
الحركية التي تضمنها البرنـامج التعليمي السمعي، في حين تفوقت المجموعة السمعية التي أستخدمت فئات وزنيـة مختلفة نتيجة لإختلاف الظروف المحيطة عن طريق تتويع أثكال تطبيق التمرينات بفئات وزنية مختلفة نتيجة تنوع الإستجابة الحركية من خلال الممارسة مع فئات وزنية مختلفة وأن هذا التتوع عزز التحكم التلقائي الداخلي بإخضاع المتعلم الى عدد من المتغيرات الممكنة لصنف الحركة ساعدت الطلاب في تحديد الهدف وتفوقهم على المجموعة السـمعية التي تعلمـت الفئة الوزنيـة نفسـها إذ يـذكر محجـوب، "التعليمـات الثـفوية لا تتطلاب مـن اللاعـب القيـام بإستجابات معينة كما هو الحال في التمرين الحقيقي وإنما القيام باستجابات شفوية لتلك الحوافز"، (محجوب، . . . ب،

ع - ع عرض ومناقشة نتائج اختبار(ت) بين المجموعتين التجريبيتين (اللمسية) الخامسة والسادسة في تعلم الاداء القني لبعض مسكات المصارعة الحرة

\section{(7) جدول (7)}

يبين نتائج اختبار (ت) للاختبارات البعدية للمجموعة اللمسية للطلاب اللذين تعلموا مع الفئة الوزنية نفسها و بفئات وزنية مختلفة للأداء الفني للمهارات التي تضمنها البرنامج التعليمي

\begin{tabular}{|c|c|c|c|c|c|c|c|}
\hline \multirow[t]{2}{*}{ قيمة (ت) } & \multicolumn{2}{|c|}{ الطلاب الأين تعلموا } & \multicolumn{2}{|c|}{ الطلاب الذين تعلموا بفئات } & \multirow{2}{*}{ وحدة القياس } & \multirow[t]{2}{*}{ مهارات المركية المعالم الاحصية } & \multirow[t]{2}{*}{$ت$} \\
\hline & $\varepsilon^{ \pm}$ & س & $\varepsilon^{ \pm}$ & س & & & \\
\hline$* Y, \Sigma \vee Y$ & $\cdot, r \cdot \varepsilon$ & $v, \cdots$ & $\cdot, 7 r 0$ & $V, \wedge \mid r$ & درجة & مسكة الرمي بحجز الرأس والذراع & -1 \\
\hline$* Y, \wedge 90$ & $\cdot, \varepsilon \vee \wedge$ & 7,7 Y & $\cdot, T / Y$ & $\vee, \vee O$. & درجة & مسكة التقاط كاحل القدم & $-r$ \\
\hline$* Y, 09 \wedge$ & $\cdot$, YO. & V, I Yo & $\cdot, 0 Y$. & $\vee, \wedge \vee 0$ & درجة & مسكة الدوران بربط الخصر & 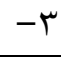 \\
\hline 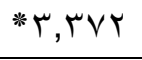 & $\cdot, \Sigma Y\rceil$ & $7,07 Y$ & $\cdot, 1$ ro & $V, r$ T & درجة & مسكة الحصير & $-\varepsilon$ \\
\hline$* Y,\urcorner \ldots$ &., 010 & $\neg, \leqslant M V$ & • ror & $V$, Yo. & درجة & مسكة العباسية & -0 \\
\hline
\end{tabular}

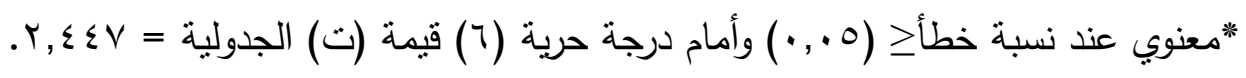

$$
\text { يتبين من الجدول (؟) ما يأتي: }
$$

بلغت قيمة (ت) المحسوبة للمهارات الاتية (مسكة الرمي بحجز الرأس والذراع، مسكة التقاط كاحل القدم،

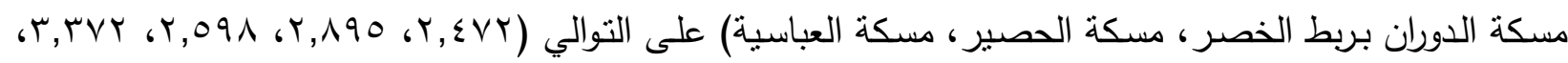

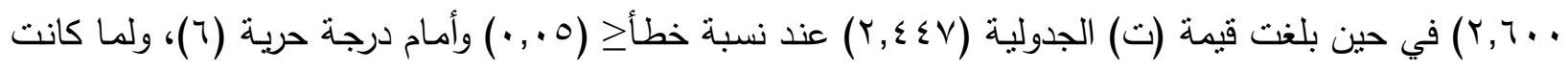
قيمـة (ت) المحسـوبة اكبر مـن قيمـة (ت) الجدوليـة، فهذا يعنـي وجـود فروق ذات دلالــة معنويـة ولصـالح طـلاب المجموعة اللمسية اللذين تعلموا بفئات وزنية مختلفة وفي ضوء النتائج التي نم التوصل اليها في الجدول (T) تبين وجود فروق معنوية في الاختبارات البعدية بين طـلاب المجموعـة اللمسية اللذين تعلموا بنفس الفئة الوزنيـة وطـلاب المجموعـة اللمسية الذين تعلموا بفئات وزنيـة مختلفة، ويمكن القول أن المجموعة اللمسية التي تعلمت مع بفئات وزنية مختلفة كانت المجموعة الأكثر تطوراً في فن الاداء المهاري للمهارات الحركية الخمس التي تضمنها البرنامج التعليمي، إذ أن استخدام التفضيل اللمسي من خلال 
تأكيد المدرس على تتميـة المستقبلات الحسية والتصرفات اللمسية للمتعلم التي تخدم الجانب الحركي لـلاداء فعند الممارسـة وتكرار تلك التمرينات التي تكون مشـابهة في أدائها لكل جزء من أجزاء المهارة المراد تعلمها(المسكات) ساعد على تتمية الإحساس الحركي السليم للأداء الفني والإقتراب من شكل طريقة الاداء لكلتا المجموعتين فضلاً عن تتوع أثكال التمربنات بفئات وزنية مختلفة للمجموعة التجريبية الخامسة خدمت الجانب الحركي نتيجة إجتماع كلا الأثرين كما عزز إستخدام الفئات الوزنية المختلفة قدرة المتعلم من الاقتراب من طريقة وشكل الاداء نتيجة تطبيقه مـع فئة وزنية أقل، كما أن التعلم مع نفس الفئة الوزنية ومنسجمة مع مستواه وقابليته ساعد على إدراك المواقف التعليمية بطريق أكثر فاعلية ونتيجة لممارسة وتكرار الأداء بفئات وزنية أكبر أعطت نتائج إيجابية نتيجة للممارسة الصحيحة مـن خـلال الاداء العملي والإقتراب مـن شـكل طريقـة الاداء الصـحيح إذ يـكر عبــ القـادر ، "إن إسـتخدام التــارين المتتوعة والمشوقة والمركبة في تطوير التعلم يعد عاملاً مهما للإرتقاء بالمستوى الفني والبدني والنفسي للمتعلم"، (عبد

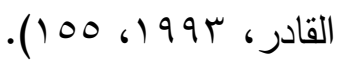
لذا وجد الباحثان من النتائج التي تم التوصل اليها في الجداول (ع،ه، ؟) وجود فروق ذات دلالة معنويـة في الاختبارات البعدية بين مجموعات البحث الثلاث (البصرية، والسمعية، واللمسية) اللذين تعلموا بفئات وزنية مختلفة كل على وفق تقضيلة الحسي، وعليه نرفض الفرضية الصفرية وتقبل الفرضية البديلة. ويعزو الباحثان هذه الفروق الى طبيعة البرامج التعليمية التي طبقت، إذ ان طبيعة وتتوع التمارين المستخدمة بفئات وزنية مختلفة كان لها تأثير واضح في تفوق المجاميع (البصرية، السمعية، اللمسية) كما أن إستخدام الفئات الوزنية المختلفة أثرت في تعلم الاداء الفني لبعض مسكات المصارعة الحرة على الرغم من التفاوت والاختلاف في نوع وطبيعة البرامج التعليمية بين تلك المجاميع وإنعكس هذا التأثنر على النتائج التي تم تحقيقها، من ان جميع العوامل سواء كانت مثيرات بصرية أم مثيرات سمعية أم مثيرات لمسية المصحوبة باستخدام فئاة وزنية مختلفة من خلال تغيير شكل التمرين وجعله اكثر سهولة بالنسبة للمتعلم من خلال تطبيقه المهارات الحركية مع فئات وزنية اقل قد ساهم في زيادة ضبط التكنيك، كما ان ادائه مـع فئات وزنية اكثر جعل التمرين اكثر صعوبة بالنسبة للمتعلم، أي أن تتوع إستخدام فئات وزنيـة مختلفة سـاعد في تكوين مسارات صـحيحة وجيدة والذي كان لـه أثر في تعلم هذه المهارات كما أن ممارسـة الطلاب لمجاميع البحث مع الفئة الوزنيـة نفسها كون لدى المتعلمين برامج حركية سهلت واعطت نتائج فعالـة في تحسين إدراك الموقف التعليمسي وإمكانيـة خزن الثـكل الحركي وتثبيت المعلومـات لتلك المهارات في الذاكرة الحركيـة بصـورة افضل من المجاميع التجريبيـة (البصرية، والسمعية، واللمسية) اللذين تعلموا الاداء الفني (المسكات) مـع الفئة الوزنية نفسـها ، ولا يتم ذلك الإ ان كانت العملية التعليميـة مصحوبة بتتوع أثنكال ومدخلات التمرين وهي من أساسيات التعلم الحركي إذ يذكر محجوب، "إذا زادت كمية المتغيرات في أنثكال التمرين

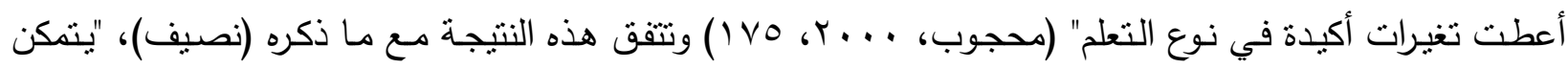
المصـارع من تطبيق مسكاته المفضله بسـولة وبتكنيك عالي ضد الخصوم اللذين هم اقل مستوى منه ومن ناحية 
اخرى يتعود على تطبيق مسكاته ضد خصم قوي ذا خبرة عالية لا ينجح في مهمته إلا بعد بذل مجهود كبير"

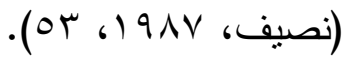
ه- 1 الاستنتاجات:

أظهر طلاب المجاميع التجربيية (البصرية، والسمعية، واللمسية) واللذين تعلموا بفئات وزنية مختلفة أفضلية التعلم على المجاميع التجريبية (البصرية، والسمعية، واللمسية) واللذين تعلموا بفئات وزنية متساوية للمسكات الخمسة التي تضمنتها البرامج التعليمية. - ب التوصيات والمقترحات

ا - إستخدام التفضيل الحسي المفضل للطلاب وبفئات وزنية مختلفة في إعداد البرامج التعليمية لما له من فؤائد في تعلم الاداء الفني لمسكات المصارعة الحرة الخمس التي تضمنها البرنامج التعليمي.

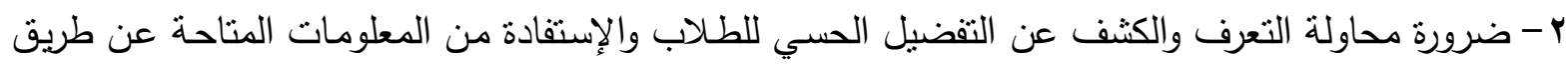
وضع البرامج التعليمية على وفق تقضيله الحسي.

\section{المصادر}

1- البطش، محمد وليد، وأبو زينة، فريد كامل (Y. (Y)،"مناهج البحث العلمي، تصميم البحث والتحليل الإحصائي"، طا ، دار الميسرة للنشر والطباعة،عمان، الأردن.

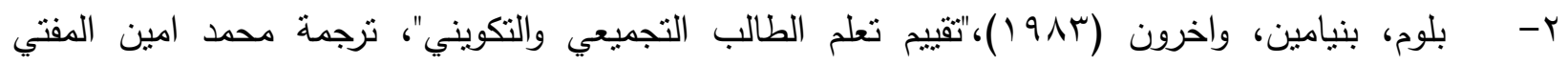

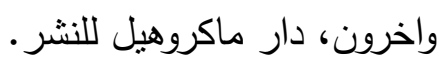
r- التكريتي، وديع ياسين والعبيدي، حسن محمد(999 (1)، "التطبيقات الإحصائية واستخدامات الحاسوب في

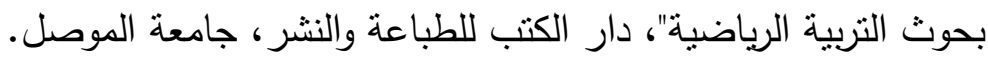
ع - حسام الدين، طلحة وآخرون( ( . ب)،" الموسوعة العلمية في التدريب الرياضي"، دار الفكر العربي،

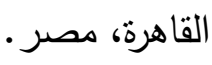
ه- حسانين، محمد صبحي (9^v (1)،" القياس والتقويم في التربية البدنية والرياضية"، دار الفكر العربي، القاهرة.

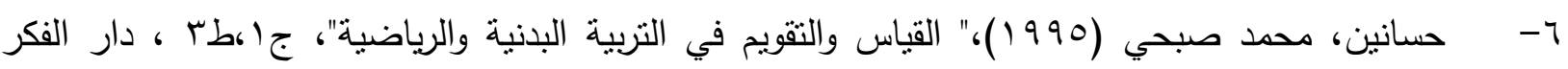
العربي، القاهرة.

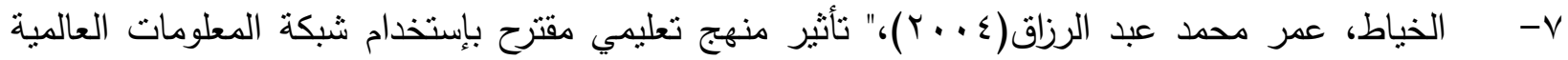
(الانترنيت في تعلم بعض المهارات الاساسية بلعبة التتس"، أطروحة دكتوراه غير منشورة، جامعة بغداد.

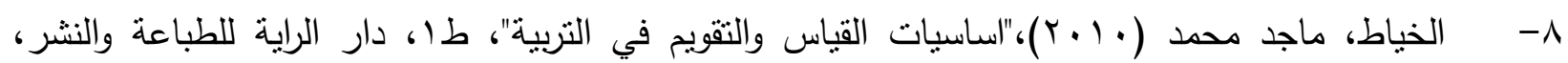

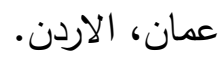

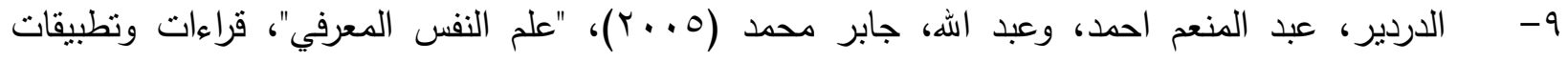
معاصرة"،ط (، عالم الكتب، القاهرة. • 1 - رضوان، محمد نصر الدين (T + . r)،"المدخل الى القياس في التربية البدنية والرياضية"،مركز الكتاب للنشر، القاهرة. 1ا -الزوبعي، عبد الجليل وآخرون (1911)، "الاختبارات والمقاييس النفسية"، دار الكتب للطباعة والنشر، جامعة 


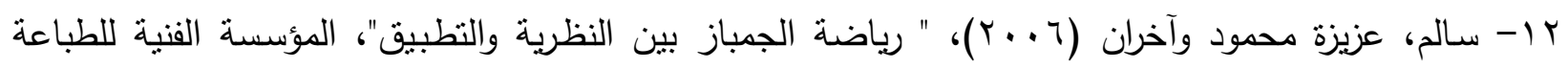
والنشر، القاهرة. rا - السلطي، نادية سميح والريماوي، محمد عودة (9 . . r)، " التعلم المستتد الى الدماغ"، دار الميسرة للنشر والطباعة،عمان، الأردن.

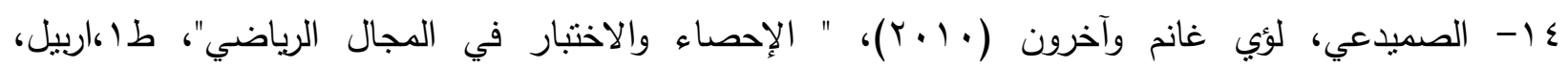
العراق. 10 - عبد القادر، محمد جميل(ب99 (19)،" التربية الرياضية الحديثة"، دار الجبل، بيروت.

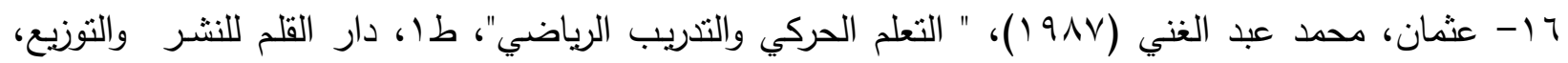
الكويت. IV - عثمان، محمد عبد الغني (•99 ())،"موسوعة العاب القوى"، مطبعة الفيصل دار القلم للنشر والتوزيع، الكويت. 1 ا - علاوي، محمد حسن ورضوان، محمد نصر الدين (rA19)،" اختبارات الاداء الحركي"،دار الفكر العربي، القاهرة. 9 ا - علاوي، محمد حسن ورضوان، محمد نصر الدين ( (...."القياس في التربية الرياضية وعلم النفس الرياضي"، دار الفكر العربي، القاهرة. • ץ- العلوان، احمد فلاح( • • r)، " أساليب التعلم المفضلة لدى طلبة المدارس الثانوية في مدينة معان في لأردن

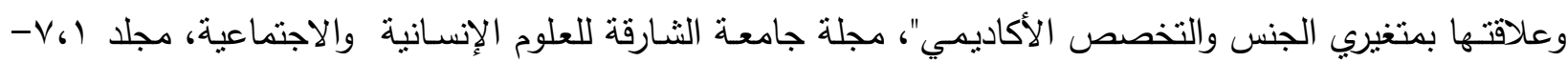
rV.

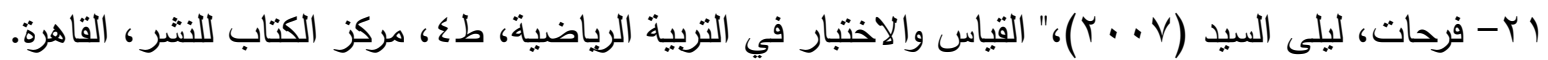

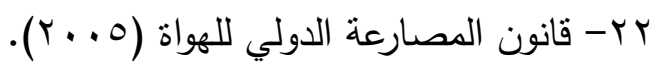
بr- الكبيسي، حمدان رحيم (r/9 ())،" اثر الطريقة الجزئية والكلية والمخلطة في تعلم فن أداء مسكات المصارعة الرومانية"،رسالة ماجستير غير منشورة، كلية التربية الرياضية، جامعة بغداد.

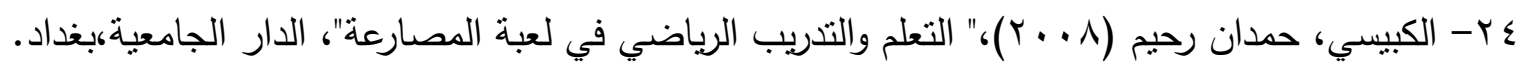
0ץ- محجوب، وجيه (910 (1)، "علم الحركة"، طا، دار الكتب للطباعة والنشر ، جامعة الموصل.

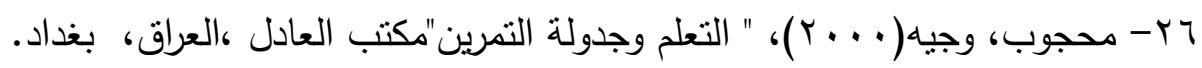

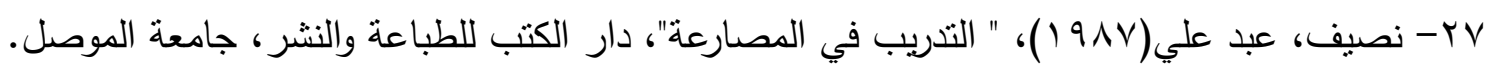
28- Best John. W. (1970), "Research in education, 2nd edition, Englewood cliffs, prentice-Hall, New Jersey. 29- Petrov, R. (1987)," Free style and Greco-Roman Wrestling published by FILA, Yugoslavia.

30-Baron. A. R. (1980),"Psychology understanding Behaver", $2^{\text {nd }}$ et Halt sanders, U.S.A. 


\section{ملحق(1) (1) (1)}

عزيزي الطالب: نكون الإجابة بوضع دائرة حول الاجابة (أ) امام العبارة إذا رأيت أنها تتطبق عليك وضع دائرة حول الإجابة (ب) إذا رأيت أن هذه العبارة لا تنطبق عليك الطيك

\begin{tabular}{|c|c|c|c|}
\hline 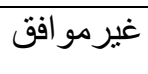 & 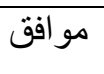 & 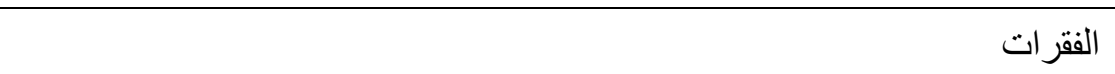 & \\
\hline ب & i & أفضل قر اءة قصة عن الاستماع اليها من شخص آخر & -1 \\
\hline$\varphi$ & أ & أفضل مشاهدة الأجهزة المرئية عن السمعية & $-r$ \\
\hline ب & أ & أتنكر الوجوه اكثر من الأسماء & $-r$ \\
\hline ب & أ & شكل خطي مهم بالنسبة لي & $-\varepsilon$ \\
\hline ب & أ & أحب قراءة الكتب التي تتضمن الصور و الرسومات & -0 \\
\hline ب & i & الاضطر اب البصري و الحركي يشتت انتباهي & -7 \\
\hline$\varphi$ & أ & أفضل مشاهدة المبار اة الرياضية عن المشاركة فيها & $-V$ \\
\hline ب & أ & أفضل تذكر الأسماء أكثر من الوجوه & $-\Lambda$ \\
\hline ب & أ & لا اجد صعوبة في تذكر التعليمات والتوجيهات الثفوية اثناء عملية التعلم & -9 \\
\hline$\varphi$ & أ & أميل الى ترديد الأصوات التي اسمعها و التفكير في معانيها & -1 \\
\hline ب & I & يتشتت انتباهي بسر عة عند سماعي لبعض الأصوات & -11 \\
\hline$\varphi$ & أ & ما أقراه أنساه بسهولة إذا لم أتحدث عنه & $-1 Y$ \\
\hline ب & أ & أفضل الاستماع الى المذياع عن مشاهدة الأجهزة المرئية & -14 \\
\hline ب & i & خطي ليس جميلا & $-1 \leq$ \\
\hline ب & أ & أفضل الاشتر اك في الألعاب الحركية اكثر من مشاهدتها & -10 \\
\hline$\varphi$ & أ & يلازم تخيلي العقلي الصور الحركية & -17 \\
\hline$\varphi$ & أ & أحب الخروج و عمل الأشياء مثل ركوب الدراجات والسباحة & $-1 V$ \\
\hline ب & أ & أتذكر الأشياء التي قتى بفعلها أكثر من الأشياء التي شاهدتها أو سمعت عنها للأنشطة & -11 \\
\hline ب & i & الخاصمة بها جهني مشكلة فأنني انتقي انسب الحلول التي تتضمن معظم الأنشطة الحركية & -19 \\
\hline ب & أ & أفضل التعلم من خلال الممارسة العملية للأنشطة الرياضية & $-r \cdot$ \\
\hline ب & i & لغة جسمي(الحركات الجسمية) تعبر عن انفعالاتي & $-Y_{1}$ \\
\hline
\end{tabular}


ملحق(ץ)

\begin{tabular}{|c|c|c|c|}
\hline الاهمية النسبية & الاختبار & الصفة البدنية والحركية & ت \\
\hline & 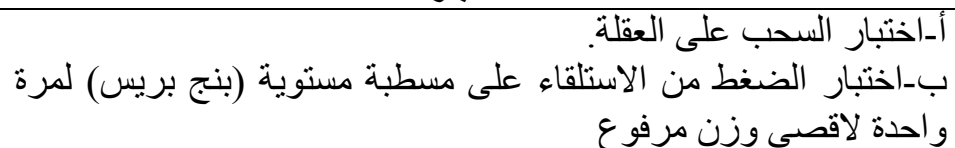 & القوة القصوى للذر اعين & -1 \\
\hline & 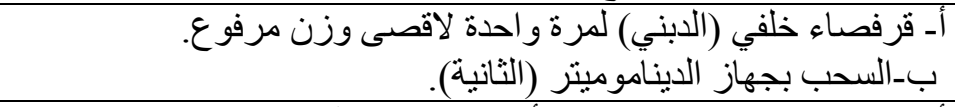 & القوة القصوى للرجلين & $r$ \\
\hline & 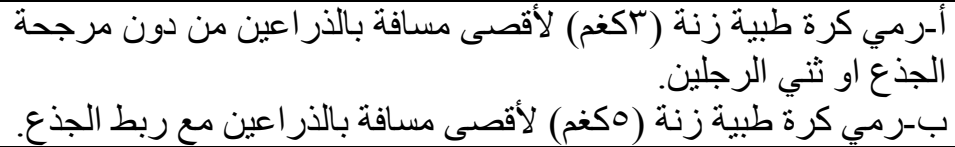 & القوة الانفجارية للذر اعين & $r$ \\
\hline & أـــــ الوثب الطويل من الثبات. & القوة الانفجارية للرجلين & $\varepsilon$ \\
\hline & 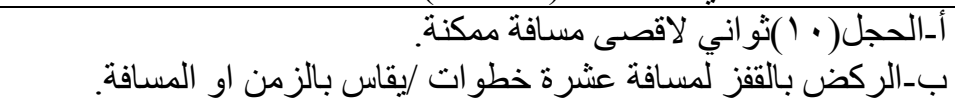 & للالقوة المين & 0 \\
\hline & 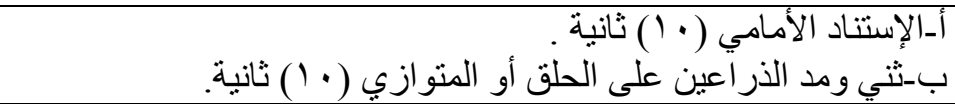 & لعضلات الذربزة اعين بالسر عة & 7 \\
\hline & 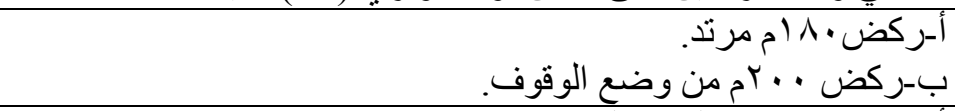 & مطاولة السر عة القصيرة & V \\
\hline & 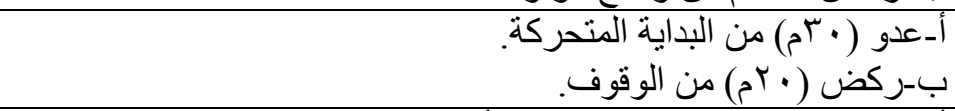 & السر عة الانتقالية & $\wedge$ \\
\hline & 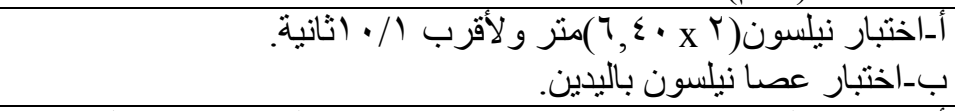 & سر عة الاستجابة الحركية & 9 \\
\hline & أقــــي التكر ارلـ الذر اعين من وضع الاستناد الامامي (الثناو)، حتى التعب او & مطاولة القوة & 1. \\
\hline & 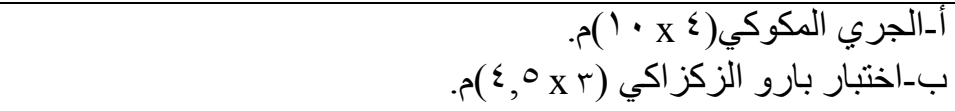 & الرشاقة & 11 \\
\hline & بـــــي الجذع من الجلوس الطويل. & المرونة & Ir \\
\hline & 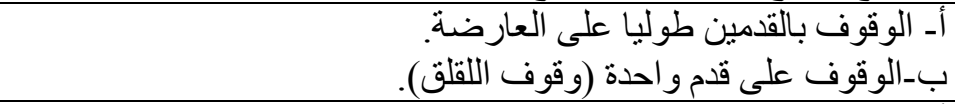 & التوازن الثابت & 14 \\
\hline & بـــاختبار الجري على شكل (8) الجري على (8) تحت عارضة الوثب. & التو افق & $1 \varepsilon$ \\
\hline & & آخرى اية صفة بدنية او حركية آختبار آخر & 10 \\
\hline
\end{tabular}




\section{ملحق (r-1}

نموذج للوحدة التعليمية للمجموعة الأولى والثانية (البصرية) اللذين تعلموا بفئات وزنية مختلفة ومتساوية الهدف من الوحدة : تعليم الطلاب مسكة الدوران بربط الخصر ومسكة الحصير

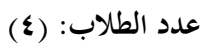

الاسبوع : الاول

الوحدة التعليمية: الأولى

الوقت : •ج د الأو

الأجهزة والأدوات : بساط مصارعة، صافرة، ساعة توقيت

\begin{tabular}{|c|c|c|c|c|c|c|}
\hline الزمن & الادا & 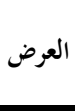 & شرح & التسماريـن & محتوى نشاط & الوحدة \\
\hline & & & & & احماء احاص عام & التحضيري \\
\hline $21 \leqslant$ & \multirow[t]{15}{*}{ צ } & \multirow[t]{15}{*}{ د } & \multirow[t]{15}{*}{ ؟ د } & يتم شرح مسكة الحصير ومسكة الدوران بربط الخصر للمجموعة البصرية لمدة (؟) & 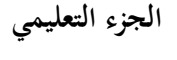 & القسم الرئيسي \\
\hline+ & & & & دقائق وعرض المسكتين من خلال النموذج (†) دقائق بعدها يتم تطبيق المسكتين من & 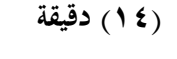 & 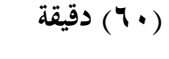 \\
\hline Y & & & & خلال التأكيد على لمس المدرس للعضو الذي يشترك بالحركة لمدة (؟) دقائق . & & \\
\hline & & & & يتم تعليم الطلاب مسكة الدوران بربط الخصر من خلال عرض المسكة باستخدام & 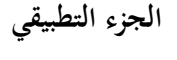 & \\
\hline \multirow[t]{11}{*}{27.} & & & & تقديم النموذج العملي امام المتعلم والتأكيد على ضرورة توجيه نظر المتعلم الى النقاط & 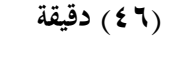 & \\
\hline & & & & الفنية الهامة المتعلم للمسار الحركي من خلال تكرار العرض لمدة (0) دقائق وتطبيق & & \\
\hline & & & & المسكة لمـدة (ه ( ) دقيقة ثم اعطاء راحة (؟) دقائق ويكون تكرار الاداء بـاوزان & & \\
\hline & & & & 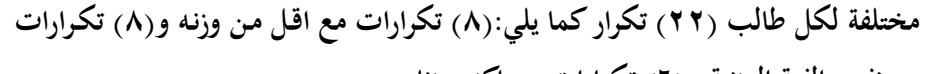 & & \\
\hline & & & & مع نفس الفئة الوزنية و(ه) تكرارات مع اكثر وزنا. & & \\
\hline & & & & يتم تعليم الطلاب مسكة الحصير من خلال عرض المسكة واستخدام تقديم النموذج & & \\
\hline & & & & العملي امام المتعلم والتأكيد على ضرورة توجيه نظر المتعلم الى النقاط الفنية الهامة & & \\
\hline & & & & المتعلم للمسار الحركي من خلال تكرار العرض لمدة (•) دقائق وتطبيق المسكة لمدة & & \\
\hline & & & & (1 (1) دقيقة ثم اعطاء راحة (ז) دقائق ويكون تكرار الاداء باوزان مختلفة لكل طالب & & \\
\hline & & & & (Y (Y) تكرار كما يلي:(^) تكرارات مـع اقل من وزنه و(^) تكرارات مع نفس الفئة & & \\
\hline & & & & الوزنية و(†) تكرارات مع اكثر وزنا. & & \\
\hline & & & & ل لعبة صغيرة- هرولة خفيفة_راحة سلبية & 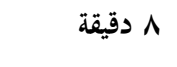 & 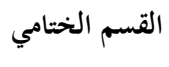 \\
\hline
\end{tabular}

"تثابه القسم التحضيري والقسم الختامي في كافة الوحدات التعليمية والاختلاف في القسم الرئيس. 


\section{ملحق (r-r)}

نموذج للوحدة التعليمية للمجموعة الثالثة والرابعة (السمعية) اللذين تعلموا بفئات وزنية مختلفة ومنساوية الهدف من الوحدة : تعليم الطلاب مسكة الدوران بربط الخصر ومسكة الحصبر

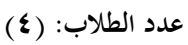

الاسبوع : الاول

الوحدة التعليمية: الأولى

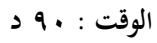

الأجهزة والأدوات : بساط مصارعة، صافرة، ساعة توقيت

\begin{tabular}{|c|c|c|c|c|c|c|}
\hline الزمن الكلي & الاداء & العرض & |الاداء & التــماريسن & الوحتوى نشاط & أوحسام \\
\hline & & & & & احماءخاص عام & التسم \\
\hline 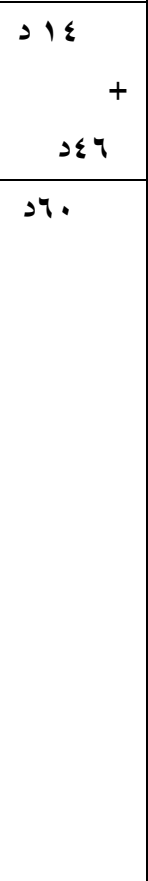 & \multirow[t]{2}{*}{ ع د } & \multirow[t]{2}{*}{ צ د } & 4 & 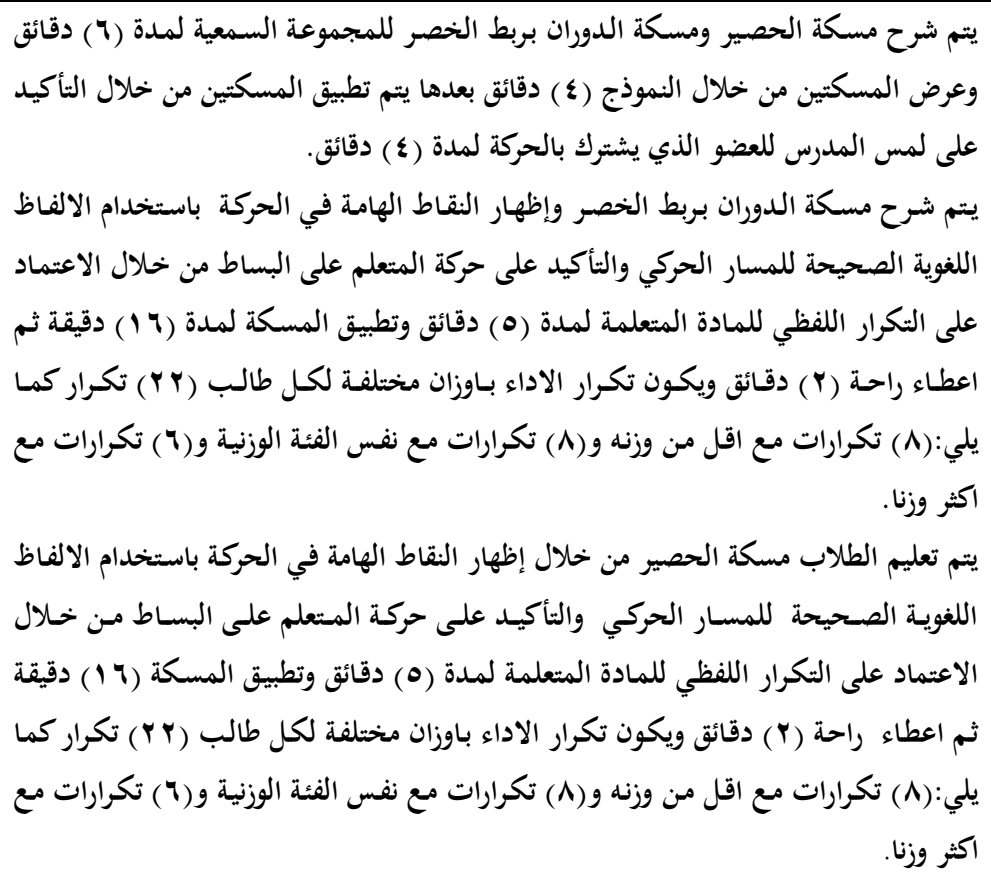 & 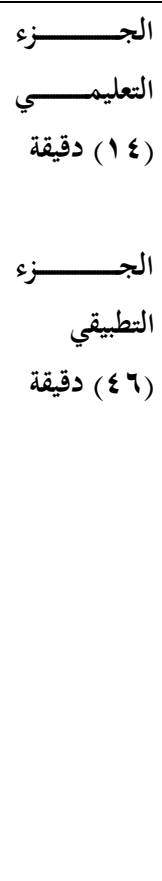 & القئيسي \\
\hline & & & & لعبة صغيرة- هرولة خفيفة_راحة سلبية & & الختميم \\
\hline
\end{tabular}




\section{ملحق (r-r)}

نموذج للوحدة التعليمية للمجموعة الخامسة والسادسة (اللمسية) اللذين تعلموا بفئات وزنية مختلفة ومتساوية الهدف من الوحدة : تعليم الطلاب مسكة الدوران بربط الخصر ومسكة الحصير

عدد الطلاب: (飞)

الاسبوع : الاول

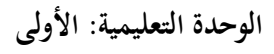

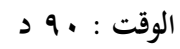

الأجهزة والأدوات : بساط مصارعة، صافرة، ساعة توقيت

\begin{tabular}{|c|c|c|c|c|c|c|}
\hline الزملي & الاداء & العرض & شرح & التــماريــن & نشاط الوحدة & الوحدة اقسام \\
\hline & & & & & احماء خاص عام & التحضم التحيري \\
\hline $\begin{array}{l}21 \leq \\
+ \\
2 \leq 4\end{array}$ & & צ د & ع د & 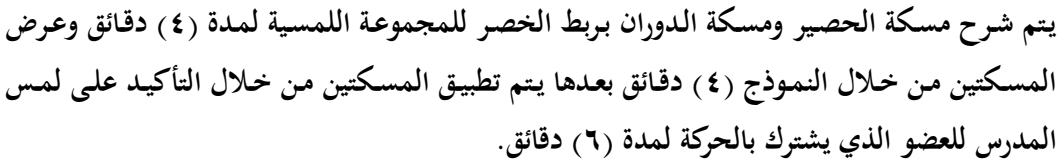 & الجزء التعليمي & الرئيسيم \\
\hline T. & & & & 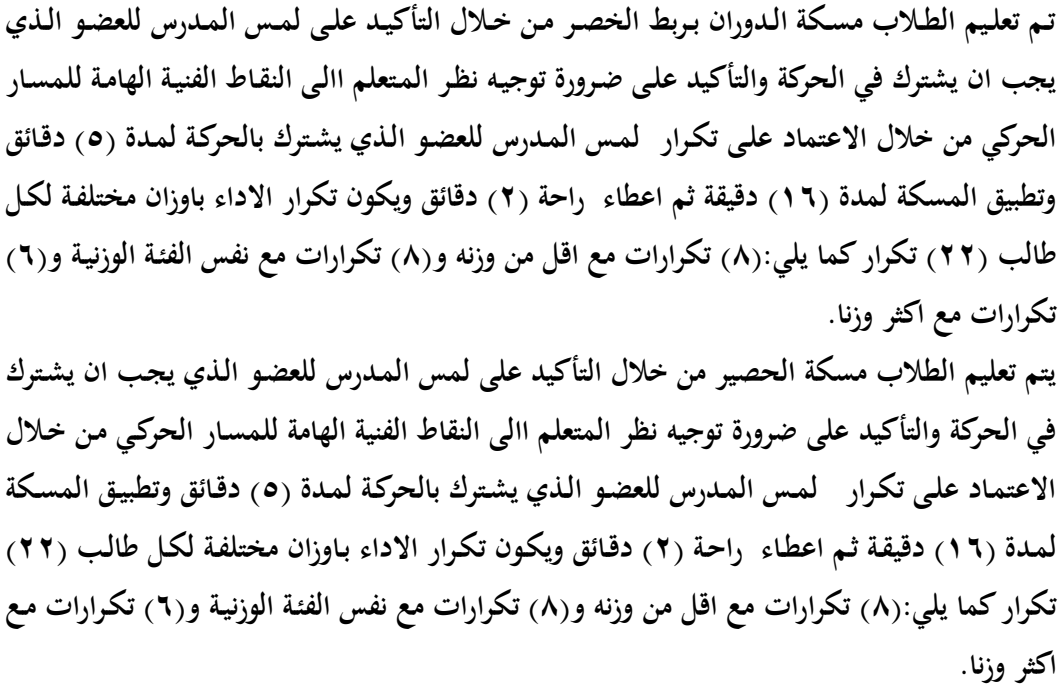 & الجزيقي & \\
\hline & & & & لعبة صغيرة- هرولة خفيفة_ راحة سلبية & ^ دقيقة & الختمي \\
\hline
\end{tabular}




$$
\text { تابع ملحق (r-r-r }
$$

نموذج لوحدة تعليمية لطبيعة الاداء للمجموعة (البصرية، السمعية، اللمسية) للأوزان المختلفة

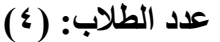

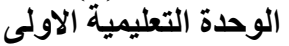

الوقت: 9 د دقيقة

الههف من الوحدة: تعليم مسكة الدوران بربط الخصر ومسكة الحصير

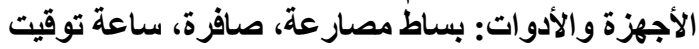

\begin{tabular}{|c|c|c|c|c|c|c|c|c|c|c|}
\hline \multicolumn{10}{|c|}{ شرح المحتوى } & \multirow{2}{*}{ 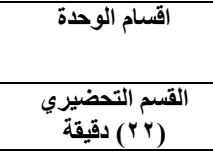 } \\
\hline & & & & & & & & & & \\
\hline \multirow[t]{2}{*}{ سرعة } & طبيعة الاداء & الراحةَّا & زلكل طالب أب & تكرار & زالطالب/ثاء ادماء & اخطاءيح & اداء & عرض & شرح & 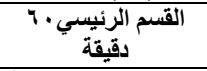 \\
\hline & & & & & & & 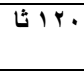 & ثاA. & Hr. & الدوران تعليطي الخصر \\
\hline بطيئة & مع فئة وزنية اقل & $1 Y-1$. & ثا. & $r$ & $10-1$. & أثا & & ثا... & & نشاط تطبيقي \\
\hline اعتيادية & فئية وزنية اقل & $1 Y-1$. & ثأ & $r$ & $10-1$. & ا ثا & & & & \\
\hline بطيئة & نفس الفئة الوزنية & $1 Y-1$. & ثأ & $r$ & $10-1$. & إثا & & & & \\
\hline اعتيادية & نفس الفئة الوزنية & $1 Y-1$. & ثا. & $r$ & $10-1$ & إثا & & & & \\
\hline اعتيادية & فئة وزنية اكثر & $1 Y-1$. & ثا. & r & $10-1$. & 10 & & & & \\
\hline اعتيادية & فئة وزنية اقل & $1 Y-1$. & ثا० & $r$ & $10-1$. & إثا & & & & \\
\hline اعتيادية & فئة وزنية اكثر & $1 Y-1$. & ثا. & $r$ & $10-1$. & آثا & & & & \\
\hline اعتيادية & نفس الفئة الوزنية & $1 Y-1$. & ثإO & 1 & $10-1$ & ثا & & & & \\
\hline اعتيادية & فئحة وزنية اكثر & $1 Y-1$. & ثا. & $r$ & $10-1$ & إ & & & & \\
\hline \multirow[t]{3}{*}{ اعتيادية } & نفس الفئة الوزنية & $1 Y-1$. & ثا. & $r$ & $10-1$. & إث & & & & \\
\hline & & ثا.-1.. & 芒. & YY & $10 \cdot-1 \ldots$ & ثا 10. & & & & المجموع \\
\hline & & & & & & & . & ثاA. & ثr. & نشاط تعليمي لمسكة \\
\hline بطيئة & مع فئة وزنية اقل & IY-1. & ثا. & $r$ & $10-1$ & ثا & & ثا.. & & نشاط تطبيقي \\
\hline اعتيادية & فئة وزنية اقل & $1 Y-1$. & ثأ & $r$ & $10-1$. & إثا & & & & \\
\hline بطيئة & نفس الفئة الوزنية & $1 Y-1$. & ثا & $r$ & $10-1$ & إ & & & & \\
\hline اعتيادية & نفس الفئة الوزنية & $1 Y-1$. & L广. & $r$ & $10-1$. & إث & & & & \\
\hline اعتيادية & فئة وزنية اكثر & $1 Y-1$. & ثا. & $r$ & $10-1$. & 足 & & & & \\
\hline اعتيادية & فئة وزنية اقل & $1 Y-1$. & ث & $r$ & $10-1$ & ا ثا & & & & \\
\hline اعتيادية & فئة وزنية اكثر & $1 Y-1$. & Lे. & $r$ & $10-1$. & إثا & & & & \\
\hline اعتيادية & نفس الفئة الوزنية & $1 Y-1$. & ثا & 1 & $10-1$. & ثا & & & & \\
\hline اعثيادية & فئة وزنية اكثر & $1 Y-1$. & ثا. & $r$ & $10-1$. & ا ثا & & & & \\
\hline \multirow[t]{2}{*}{ اعتيادية } & نفس الفئة الوزنية & $1 Y-1$. & Lेr. & $r$ & $10-1$. & آثا & & & & \\
\hline & & ثا.-1.. & . & rr & $10 \cdot-1 \ldots$ & ثا & & & & المجموع \\
\hline & & & & & & & & & & القسم الختامي (^) \\
\hline
\end{tabular}

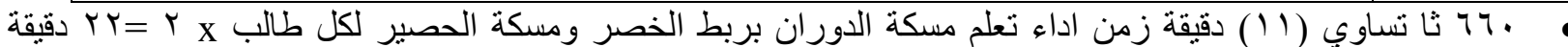

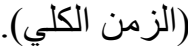

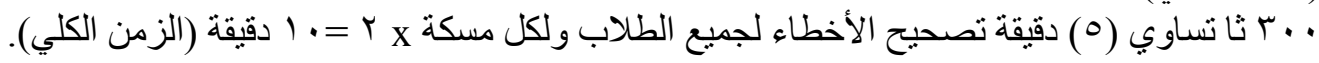

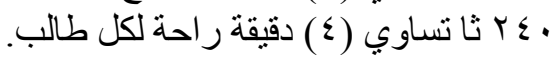

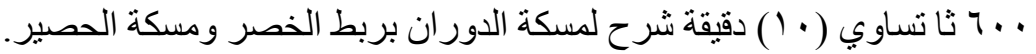
• 


\section{ملحق (६)}

أسماء السادة الخبراء والمختصين المشاركين بآرائهم العلمية في كافة إجراءات البحث

\begin{tabular}{|c|c|c|c|c|c|c|c|}
\hline فإستبمارة & التبليمامجية & الصنبارات & التفضياسلات & مكان العمل & الاسم & اللعمي & 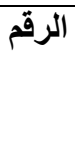 \\
\hline & & * & & التربية/الرياضية/جامعة الموصل & وديع ياسين التكريتي & أ.د. & -1 \\
\hline & & & * & التربية الرياضية/جامعة تكريت & كامل طه الويس & أ.د. & $-{ }^{-1}$ \\
\hline & & & * & التربية الرياضية/جامعة بغداد & نوري إبر اهيم الشوك & أ.د. & $-r$ \\
\hline & & * & & التربية|الرياضية/جامعة الموصل & ياسين طه محمد علي & 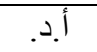 & $-\varepsilon$ \\
\hline & & * & & التربية|الرياضية/جامعة الموصل & ضياء مجيد الطالب & أ..د. & -0 \\
\hline & * & & & التربية/الرياضية/جامعة الموصل & عامر محمد سعودي & أ.د. & -7 \\
\hline & * & & & التربية/الرياضية/جامعة الموصل & جاسم محمد نايف & أ.د. & $-V$ \\
\hline & & * & & التربية/الرياضية/جامعة الموصل & عناد جرجيس عبد الباقي & 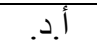 & $-\Lambda$ \\
\hline & * & & & التربية/الرياضية/جامعة الموصل & وليد و عد الله علي & أ.د. & -9 \\
\hline & & & * & التربية/الرياضية/جامعة الموصل & ن اظظم شاكر الوتار & أ.د. & -1. \\
\hline & * & & & التربية|الرياضية/جامعة الموصل & طلال نجم عبد الله & أ.د. & -11 \\
\hline * & * & * & & التربية|الرياضية/جامعة الموصل & حازم احمد مطرود & أ.ج.د. & $-1 T$ \\
\hline & & & * & كلية التربية/جامعة الموصل & ندى فتاح زيدان & أ. أ.د.د. & -14 \\
\hline & & & * & كلية التربية/جامعة الموصل & صبيحة ياسر كطوف & أ.م.د. & $-1 \varepsilon$ \\
\hline * & * & * & & التربية/الرياضية/جامعة الموصل & ليث محمد داؤد & أ.ج.د. & -10 \\
\hline & & & * & كلية/المعلمين/التربية الاساسية & عكلة سليمان علي & أ. أ.د.د. & -17 \\
\hline & & & * & كلية التربية/جامعة الموصل & أسامة حامد محمد & أ.م.د. & $-1 V$ \\
\hline & & & * & كلية المعلمين/التربية الاساسية & معيوف ذنون حنتوش & أ.ج.د. & -11 \\
\hline * & & & & التربية/الرياضية/جامعة الموصل & سلو ان خالد محمود & م.د. & -19 \\
\hline
\end{tabular}

\section{ملحق(•)}

استمارة تقويم بعض مسكات لعبة المصارعةالحرة لمجاميع البحث الست بصورتها النهائية

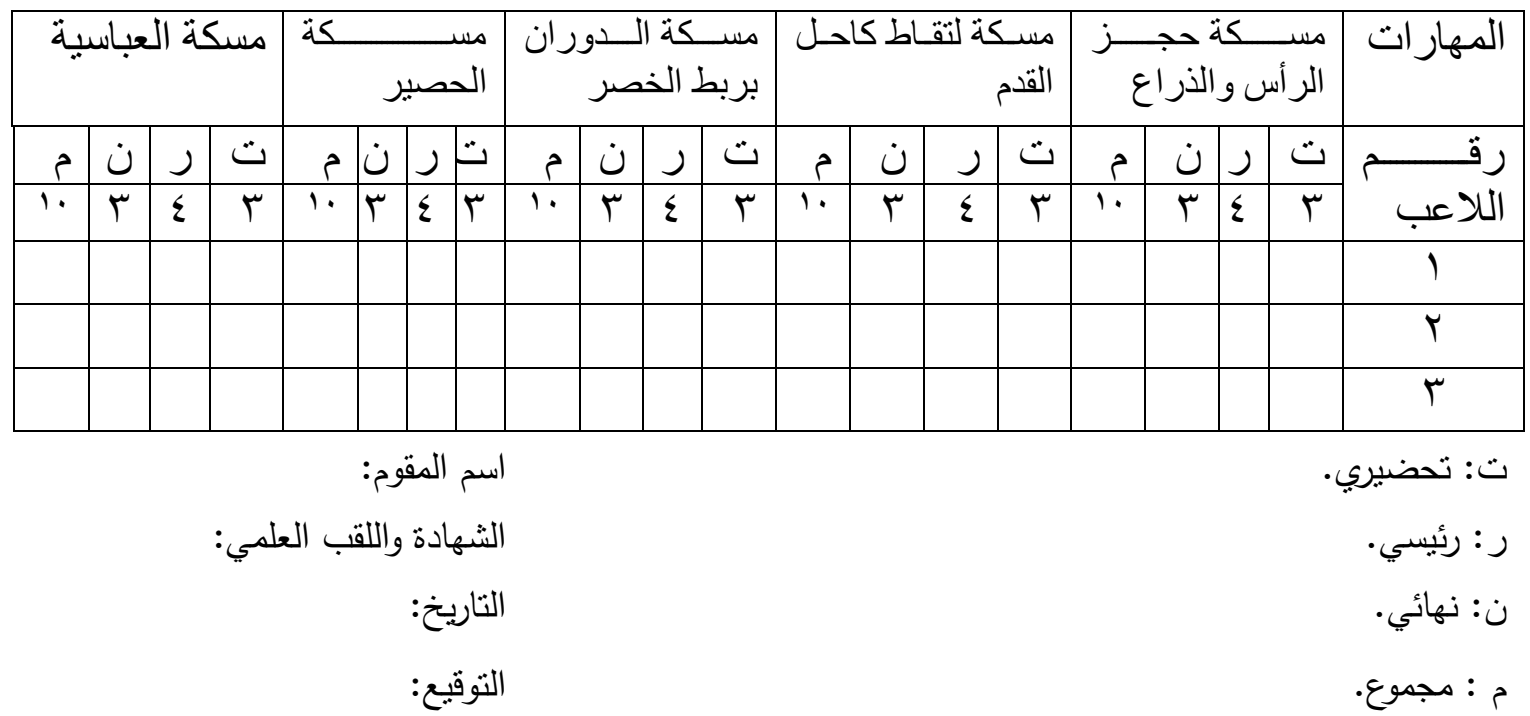

